\title{
Pethia lutea, A neW SPECIES Of bARB (TEleostel: CyPRINIDAe) AND NEW RECORDS OF P. PUNCTATA FROM NORTHERN WESTERN GHATS OF INDIA
}

\author{
Unmesh Katwate ${ }^{1}$, Chetana Katwate ${ }^{2}$, Rajeev Raghavan ${ }^{3}$, Mandar S. Paingankar ${ }^{4}$ \& \\ Neelesh Dahanukar ${ }^{5}$
}

ISSN

Online 0974-7907 Print 0974-7893

OPEN ACCESS

${ }^{1,2}$ Bombay Natural History Society Hornbill House, Opp. Lion Gate, Shaheed Bhagat Singh Road, Mumbai, Maharashtra 400001, India

${ }^{3}$ Conservation Research Group (CRG), St. Albert's College, Banerji Road, Kochi, Kerala 682018, India

$3,4,5$ Systematics, Ecology \& Conservation Laboratory, Zoo Outreach Organization (ZOO), 96 Kumudham Nagar, Vilankurichi Road, Coimbatore, Tamil Nadu 641035, India

${ }^{5}$ Indian institute of Science Education and Research, Dr. Homi Bhabha Road, Pashan, Pune, Maharashtra 411008, India

${ }^{1}$ theunmesh@gmail.com, ${ }^{2}$ chetanak72@gmail.com, ${ }^{3}$ rajeevraq@hotmail.com, ${ }^{4}$ mandarpaingankar@gmail.com,

${ }^{5}$ n.dahanukar@iiserpune.ac.in (corresponding author)

Abstract: A new species of barb Pethia lutea is described from the Kundalika River in the northern part of the Western Ghats. The new species can be distinguished from its congeners in India based on a combination of characters including a distinct humped nape, absence of barbels, complete lateral line, lips thick, lateral fold on snout, 19-22 lateral line scales, 8 predorsal scales, 9-10 prepelvic scales, 14-15 preanal scales, $4-4 \frac{1}{2}$ transverse scale rows between lateral line and dorsal fin origin, $2 \frac{1}{2}-3$ transverse scale rows between lateral line and pelvic fin base, 6-9 pair of serrae on the distal half of the dorsal fin spine, 13-15 branched pectoral fin rays, 7 branched pelvic fin rays, $4+26$ total vertebrae, 4+13 abdominal and 13 caudal vertebrae, body with one vertical humeral and one caudal blotch and dorsal fin without any bands or blotches. Additionally, we provide new records of Pethia punctata from the rivers of Maharashtra State along with a description of its osteology.

Keywords: Conservation status, distribution, freshwater fish, Maharashtra, taxonomy.

DOI: http://dx.doi.org/10.11609/JoTT.03929.5797-818 | ZooBank: urn:Isid:zoobank.org:pub:27215C3C-B61E-4001-8234-91C00EFDA743

Editor: Anonymity requested.

Date of publication: 26 June 2014 (online \& print)

Manuscript details: Ms \# 03929 | Received 29 January 2014 | Final received 18 May 2014 | Finally accepted 02 June 2014

Citation: Katwate, U., C. Katwate, R. Raghavan, M.S. Paingankar \& N. Dahanukar (2014). Pethia lutea, a new species of barb (Teleostei: Cyprinidae) and new records of $P$. punctata from northern Western Ghats of India. Journal of Threatened Taxa 6(6): 5797-5818; http://dx.doi.org/10.11609/JoTT.03929.5797-818

Copyright: @ Katwate et al. 2014. Creative Commons Attribution 4.0 International License. JoTT allows unrestricted use of this article in any medium, reproduction and distribution by providing adequate credit to the authors and the source of publication.

Funding: The study was partially funded by small grants of the Critical Ecosystem Partnership Fund (CEPF) small grant through the Ashoka Trust for Research in Ecology and Environment to UK (CEPF-ATREE-WGhats/SGP/WGSG186-BNHS_FISHES) and partially by DST-INSPIRE Faculty Fellowship to ND. RR thanks the North of England Zoological Society (NEZS)-Chester Zoo for funding.

Competing Interests: The authors declare no competing interests. Funding sources had no role in study design, data collection, results interpretation and manuscript writing.

Author Contribution: UK, CK, RR, MP, ND collected specimens. UK, CK performed the morphological and osteological studies. MP, ND performed the genetic analysis. UK, RR, ND studied museum specimens. UK, CK, RR, MP, ND wrote the manuscript.

Acknowledgements: We thank Rajendra Pawar, Rupesh Raut, Vishwas, Abhijit and Saurabh for helping with the collections; Karsten E. Hartel Curatorial Associate, Museum of Comparative Zoology, Harvard University, for helpful discussion and providing image of Francis Day's material of Puntius punctatus; Asad Rahmani, Director; Deepak Apte, COO; Rahul Khot, In-Charge Natural History Collection department, for their help during study of the museum specimens and registration of specimens in Bombay Natural History Society (BNHS), Mumbai; Sanjay Molur, Executive Director; and Priyanka lyer, curator of fish collection, for holding our specimen vouchers in the museum collection of Wildlife Information Liaison Development (WILD) Society, Coimbatore; the Director, Zoological Survey of India and Officer In-Charge of the ZSI Collections for providing us the access to the type material of the species; Shrikant Jadhav for his help while studying some of the type material; Ralf Britz for his help in accessing Day's material in the collections of the Natural History Museum, London.
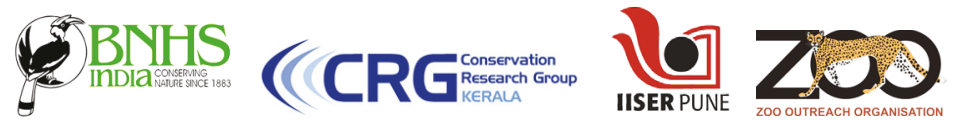

CRITICAL $\mid$ ECOSYSTEM PARTEERSHIP FUND

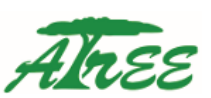




\section{INTRODUCTION}

Genus Pethia is characterized by small adult size, absence of rostral barbels, maxillary barbels rudimentary or absent, last unbranched dorsal fin rays osseous and serrated on posterior edge, 3-4 branched and eight branched dorsal fin rays, three unbranched and five branched anal fin rays, 11-13 precaudal and 13-16 caudal vertebrae, complete or incomplete lateral with 19-24 scales in lateral series-except $P$. sharmai (Menon \& Devi 1993), which has 42 scales-and lateral color pattern consisting of a black blotch on caudal peduncle with other black blotches, spots or bars often present (Pethiyagoda et al. 2012; Knight 2013). The genus is currently known to be endemic to South Asia and Myanmar and comprises 35 species (Pethiyagoda et al. 2012; Knight 2013; Dishma \& Vishwanath 2013; Kottelat 2013; Gurung et al. 2013). In India the genus is represented by 23 species, with seven found in river systems originating in the Western Ghats.

Pethia ticto (Hamilton, 1822) has long been considered as a widely distributed species found throughout the Indian subcontinent (Hora et al. 1939; Jayaram 2010). However, recent studies have suggested that fish previously considered $P$. ticto represent a complex of several valid species (Beevi \& Ramachandran 2005; Linthoingambi \& Vishwanath 2007; Mercy \& Jacob 2007; Knight et al. 2012), with P. ticto sensu stricto possibly restricted to the Ganges and Brahmaputra watershed. Several records of $P$. ticto from both east and west flowing rivers in the northern part of the Western Ghats need taxonomic validations, as they might comprise one or more distinct species.

While exploring the diversity of Pethia from the Western Ghats of Maharashtra, we came across a species distinctly different from its congeners, which we describe as Pethia lutea.

\section{MATERIALS AND METHODS}

\section{Study site and sampling}

Fishes were collected from seven localities in five west flowing river systems, viz., Ulhas, Kal, Kundalika, Savitri and Shastri, part of the northern Western Ghats in Maharashtra State, India. The specimens were collected responsibly and not more than three specimens were collected from each site, except for the type locality where six specimens were collected. In addition, seven specimens of Pethia punctata were collected from Gad and Terekhol River systems.

\section{Voucher specimens and museum abbreviations}

Voucher specimens are deposited in the museum collections of the Bombay Natural History Society (BNHS), Mumbai; the Wildlife Information Liaison Development (WILD) Society, Coimbatore; the Zoological Survey of India, Western Regional Center, Pune (ZSIWRC) and the Conservation Research Group, St. Albert's College (CRG-SAC), Kochi. Other material examined are in the museum collections of the Zoological Survey of India, Kolkata (ZSI-K); Natural History Museum, London (BMNH) and the Museum of Comparative Zoology, Harward University (MCZ).

\section{Morphological and morphometric analysis}

Measurements were taken point to point using dial calipers to the nearest $0.1 \mathrm{~mm}$. Subunits of the body are presented as percent of standard length (SL), and subunits of the head are presented as percent of head length $(\mathrm{HL})$. All pored scales were counted when reporting the lateral line scales. Methods for taking counts and measurements follow Kullander (2008) and Pethiyagoda et al. (2012).

\section{Osteology}

Two specimens, BNHSFWF 79 and BNHS FWF 88, were cleared and stained following the procedure described by Potthoff (1984). Osteological nomenclature follows Conway (2011) and the description of osteology follows Pethiyagoda et al. (2012) and Dishma \& Vishwanath (2013) for easy comparison with other related taxa. Illustrations were made from images captured by a digital camera fitted on stereo-zoom light microscope (Leica S8 APO, USA).

\section{Phylogenetic analysis}

Gills were harvested from proposed new species (BNHS FWF 78, BNHS FWF 73 and WILD-14-PIS-064), P. punctata (WILD-14-PIS-103, BNHS FWF 89, BNHS FWF 90 and BNHS FWF 91), P. setnai (WILD-13-PIS-043, WILD-13-PIS-046, BNHS FWF 53 and BNHS FWF 54) and $P$. phutunio (BNHS FWF 95) and were preserved in absolute Ethanol. DNA extraction, PCR amplification for cytochrome b (cytb) and cytochrome oxidase subunit I (COI) gene sequences and sequencing protocols follow Katwate et al. (2013) and Ali et al. (2013). Sequences were analyzed by BLAST tool (Altschul et al. 1990). All sequences generated as part of the study have been deposited in GenBank under the accession numbers KJ681103-KJ681117.

We used the cytb gene sequence data from Katwate et al. (2013), while COI gene sequences for Pethia and 
related genera were downloaded from NCBI GenBank (http://www.ncbi.nlm.nih.gov/). GenBank accession numbers for sequences are provided in respective figures. Gene sequences were aligned using MUSCLE (Edgar 2004). Molecular phylogeny was performed using the freeware MEGA 6 (Tamura et al. 2013). Best fit model for nucleotide substitution was selected from 24 models using MEGA 6 (Tamura et al. 2013) based on minimum Bayesian Information Criterion (BIC) value (Schwarz 1978; Nei \& Kumar 2000). Maximum likelihood tree was built based on the best fit model and reliability of the phylogenetic tree was estimated using bootstrap values run for 1000 iterations.

\section{RESULTS}

\section{Taxonomy}

\section{Pethia lutea sp. nov.}

(Image 1 and Table 1)

urn:Isid:zoobank.org:act:40594E11-1796-44FD-8822-9CD2CDD5A1A9

\section{Type material}

Holotype: BNHS FWF 71, 23.xii.2012, 30.8mm SL, Bhira $\left(18.441^{\circ} \mathrm{N} \& 73.267^{\circ} \mathrm{E}\right.$, elevation $\left.50 \mathrm{~m}\right)$, Kundalika River, Raigad District, Maharashtra, India, coll. Unmesh Katwate and Chetana Katwate.

Paratypes $(n=21): 3$ exs., BNHS FWF 72, 78 and 79, 23.xii.2012, 31.0-35.1 mm SL, Bhira $\left(18.441^{\circ} \mathrm{N}\right.$ \& $\left.73.267^{\circ} \mathrm{E}, 50 \mathrm{~m}\right)$, Kundalika River, Raigad District, Maharashtra, India, coll. Unmesh Katwate and Chetana Katwate; 1 ex., WILD-14-PIS-061, 23.xii.2012, 35.0mm
SL, Bhira $\left(18.441^{\circ} \mathrm{N} \& 73.267^{\circ} \mathrm{E}, 50 \mathrm{~m}\right)$, Kundalika River, Raigad District, Maharashtra, India, coll. Unmesh Katwate and Chetana Katwate; 1 ex., ZSI-WRC-3686, 23.xii.2012, 30.5mm SL, Bhira $\left(18.441^{\circ} \mathrm{N} \& 73.267^{\circ} \mathrm{E}\right.$, $50 \mathrm{~m})$, Kundalika River, Raigad District, Maharashtra, India, coll. Unmesh Katwate and Chetana Katwate; 3 exs., BNHS FWF 73, 80 and 81, 23.vi.2012, 33.2-39.0 $\mathrm{mm}$ SL, Karjat $\left(18.922^{\circ} \mathrm{N} \& 73.332^{\circ} \mathrm{E}, 48 \mathrm{~m}\right)$, Ulhas River, Raigad District, Maharashtra, India, coll. Neelesh Dahanukar and M. Paingankar; 2 exs., BNHS FWF 74 and 82, 05.i.2013, 31.0mm and 31.70mm SL, Mangaon $\left(18.233^{\circ} \mathrm{N} \& 73.256^{\circ} \mathrm{E}, 7 \mathrm{~m}\right)$, Kal River - tributary of Savitri River, Raigad District, Maharashtra, India, coll. Unmesh Katwate and Chetana Katwate; 1 ex., BNHS FWF 75, 23.ix.2013, 26.2mm SL, Mahad $\left(18.091^{\circ} \mathrm{N} \& 73.466^{\circ} \mathrm{E}\right.$, $16 \mathrm{~m})$, Savitri River, Raigad District, Maharashtra, India, coll. Unmesh Katwate, Chetana Katwate, Rajendra Pawar and Vishwas Shinde; 1 ex., WILD-14-PIS-062, 23.ix.2013, $22.5 \mathrm{~mm}$ SL, Mahad $\left(18.091^{\circ} \mathrm{N} \& 73.466^{\circ} \mathrm{E}, 16 \mathrm{~m}\right)$, Savitri River, Raigad District, Maharashtra, India, coll. Unmesh Katwate, Chetana Katwate, Rajendra Pawar and Vishwas Shinde; 1 ex., ZSI-WRC-3687, 23.ix.2013, 23.4mm SL, Mahad $\left(18.091^{\circ} \mathrm{N} \& 73.466^{\circ} \mathrm{E}, 16 \mathrm{~m}\right)$, Savitri River, Raigad District, Maharashtra, India, coll. Unmesh Katwate, Chetana Katwate, Rajendra Pawar and Vishwas Shinde; 1 ex., BNHS FWF 76, 26.xi.2013, 25.2mm SL, Shivathar Ghal $\left(18.148^{\circ} \mathrm{N} \& 73.619^{\circ} \mathrm{E}, 145 \mathrm{~m}\right)$, Savitri River, Raigad District, Maharashtra, India, coll. Unmesh Katwate, Chetana Katwate, Rajendra Pawar and Vishwas Shinde; 1 ex., WILD-14-PIS-063, 26.xi.2013, 30.7mm SL, Shivathar Ghal $\left(18.148^{\circ} \mathrm{N} \& 73.619^{\circ} \mathrm{E}, 145 \mathrm{~m}\right)$, Savitri River, Raigad

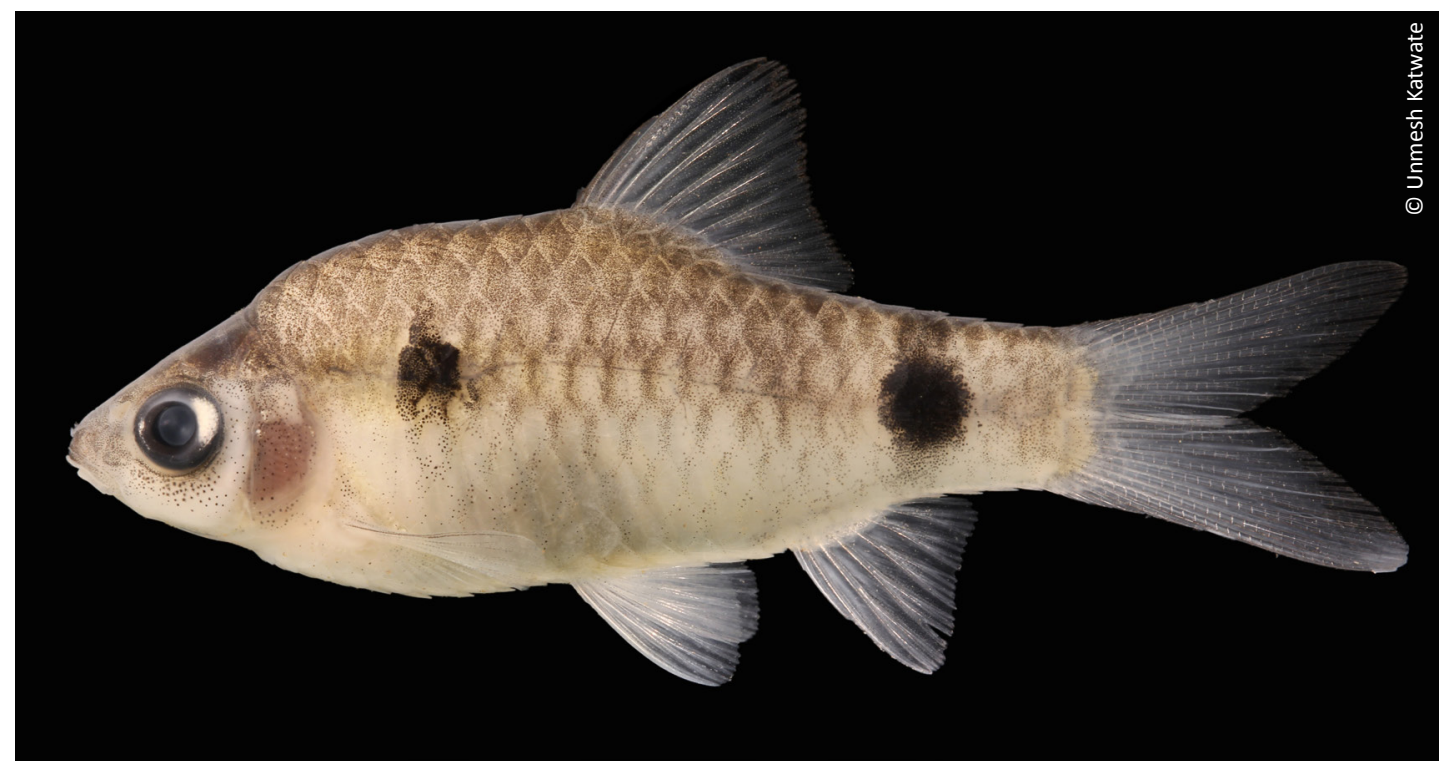

Image 1. Holotype of Pethia lutea sp. nov. (BNHS FWF 71) 
Table 1. Morphometric characters and meristics of Pethia lutea sp. nov. Raw morphometric data is provided in Appendix A.

\begin{tabular}{|c|c|c|c|}
\hline \multirow{2}{*}{ Morphometry } & \multirow{2}{*}{ Holotype } & \multicolumn{2}{|c|}{ Paratypes $(n=21)$} \\
\hline & & Mean (sd) & Range \\
\hline Total length (mm) & 40.2 & $37.0(6.4)$ & $28.2-49.4$ \\
\hline Standard length (SL, mm) & 30.8 & $28.6(5.5)$ & 20.9-38.9 \\
\hline \multicolumn{4}{|l|}{$\% S L$} \\
\hline Head length $(\mathrm{HL})$ & 27.2 & $27.1(1.4)$ & $24.4-30.2$ \\
\hline Head depth & 23.7 & $23.2(0.8)$ & $21.4-30.2$ \\
\hline Head width & 16.2 & $15.7(0.6)$ & $14.2-16.4$ \\
\hline Body depth & 36.2 & $34.2(1.4)$ & $31.2-37.3$ \\
\hline $\begin{array}{l}\text { Body width at dorsal fin } \\
\text { origin }\end{array}$ & 17.0 & $14.9(1.5)$ & $10.7-17.0$ \\
\hline $\begin{array}{l}\text { Body width at anal fin } \\
\text { origin }\end{array}$ & 12.8 & $10.9(1.9)$ & $5.5-13.3$ \\
\hline Pre dorsal distance & 52.0 & $51.8(0.7)$ & $50.4-52.9$ \\
\hline Dorsal to hypural distance & 49.6 & $48.3(1.1)$ & $45.9-50.3$ \\
\hline Prepelvic distance & 50.7 & $50.1(1.1)$ & $47.2-52.7$ \\
\hline Preanal distance & 71.6 & $71.8(1.8)$ & $69.2-76.8$ \\
\hline Prepectoral distance & 27.9 & $28.4(1.5)$ & $25.8-31.2$ \\
\hline Dorsal fin length & 22.5 & $26.9(2.2)$ & $22.5-31.2$ \\
\hline Dorsal fin spine length & 18.1 & $18.1(2.4)$ & $13.7-23.9$ \\
\hline Length of dorsal fin base & 16.0 & $15.9(1.0)$ & $12.9-17.8$ \\
\hline Pectoral fin length & 19.1 & $21.0(1.2)$ & $18.4-24.2$ \\
\hline Anal fin depth & 18.0 & $19.6(1.4)$ & $14.8-21.5$ \\
\hline Caudal peduncle length & 20.0 & $20.0(1.1)$ & $17.8-22.0$ \\
\hline Caudal peduncle depth & 15.4 & $14.7(0.6)$ & $13.4-22.7$ \\
\hline \multicolumn{4}{|l|}{$\% \mathrm{HL}$} \\
\hline Head depth & 87.1 & $85.6(4.6)$ & $76.4-93.7$ \\
\hline Head width & 59.7 & $57.8(2.1)$ & $54.3-61.1$ \\
\hline Snout length & 26.3 & $25.9(1.4)$ & $21.9-28.2$ \\
\hline Eye diameter & 30.8 & $32.3(1.7)$ & $29.3-35.0$ \\
\hline Inter orbital width & 36.7 & $37.1(2.8)$ & $31.4-40.8$ \\
\hline \multicolumn{4}{|l|}{ Meristics } \\
\hline Lateral line scale & 22 & & $19-22$ \\
\hline Transverse scale rows & $1 / 24 / 1 / 3$ & & $\begin{array}{c}4-1 / 24 / 1 / 2^{1 / 2-} \\
3\end{array}$ \\
\hline Predorsal scale & 8 & & 8 \\
\hline Prepelvic scale & 9 & & $9-10$ \\
\hline Preanal scale & 14 & & $14-15$ \\
\hline Circumpeduncular scales & 12 & & 12 \\
\hline DF ray & iii 8 & & iii 8 \\
\hline Pectoral fin ray & i 13 & & i $13-15$ \\
\hline Pelvic fin ray & i 7 & & i 7 \\
\hline Anal fin ray & iii 5 & & iii 5 \\
\hline Caudal fin ray (principal) & $6+6$ & & $6-7+6-7$ \\
\hline Caudal fin rays (branched) & $8+9$ & & $8-9+8$ \\
\hline
\end{tabular}

Pethia lutea sp. nov. can be distinguished from its congeners based on a combination of prominent characters including a distinct humped nape; complete lateral line; absence of barbels; lips fleshy; distinct lateral fold on snout; 19-22 pored lateral line scales; eight predorsal scales; 9-10 prepelvic scales; $14-15$ preanal scales; $4 \frac{1}{2}-4$ scales between dorsal fin origin and lateral line, and $2 \frac{1}{2}-3$ scale between lateral line and pelvic fin origin; last simple dorsal fin ray strong and serrated with 6-9 serrae on distal half of spine whereas 2-4 on apical half of spine; $13-15$ branched pectoral fin rays; seven branched pelvic fin rays; caudal fin with 6-7+6-7 principal rays and 8-9+8-9 branched rays; 5 supraneurals; 6 predorsal neural spine; deep and enlarged infraorbital three; gill rakers three on epibranchial, one at angle and 14-15 on first ceratobranchial; one humeral band covering $3^{\text {rd }}$ and $4^{\text {th }}$ lateral line scale and extends to one scale up and down; one caudal blotch encircling caudal peduncle dorsally covering $17^{\text {th }}-19^{\text {th }}$ lateral line scale; dorsal fin without any bands and body dark yellow with iridescence on scale.

\section{Description}

Morphometric and meristic data of the holotype and 21 paratypes are provided in Table 1 . Photographs of the holotype and paratypes in live and preserved conditions from different localities are provided in Images 1, 2 and 4 , while, osteological details are provided in Image 3 and Fig. 1.

Body moderately deep, compressed laterally; dorsal profile from tip of snout to occiput plain, humped at nape immediately posterior to occiput, rising gradually up to 


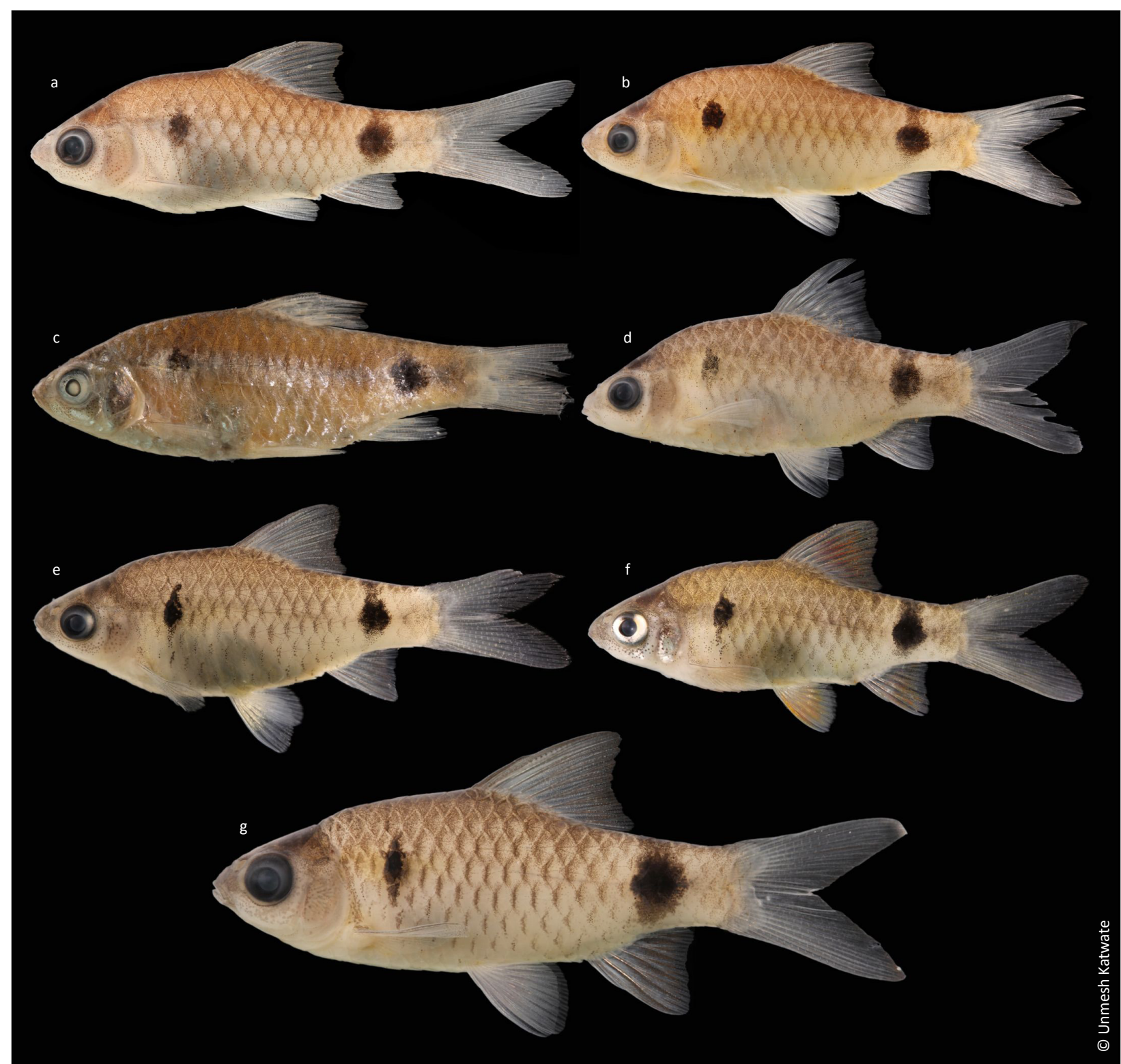

Image 2. Paratypes of Pethia lutea sp. nov. from different localities showing morphological variations.

a - Kundalika (BNHS FWF 72), b - Bhira (WILD-14-PIS-061), c - Karjat (BNHS FWF 73), d - Mangaon (BNHS FWF 74), e - Mahad (BNHS FWF 75),

f - Shivathar Ghal (BNHS FWF 76), and g - Sangameshwar (BNHS FWF 77).

dorsal-fin origin, thereafter sloping gradually towards hypural notch. Ventral profile moderately convex up to posterior end of anal-fin base, sloping gradually towards hypural notch. Caudal peduncle longer than deep, its length 1.2-1.5 times its depth.

Head small, laterally compressed. Snout rounded, smooth, shorter than eye diameter, with a distinct lateral fold overhanging upper lip. Mature males with breeding tubercles on snout, cheek, nape and dorsum. Eyes large, dorso-laterally positioned, closer to snout tip than end of operculum, its diameter less than or equal to interorbital width. Mouth small, subterminal, ventrally ' $U$ ' shaped, gape of mouth not reaching to vertical from anterior margin of eye. Lips fleshy, lower lip not interrupted. Barbels absent.

Dorsal fin origin opposite to pelvic fin origin, slightly closer to caudal fin than to tip of snout, its distal margin concave, its height more or less equal to head length $(82.6-109.8 \% \mathrm{HL})$. Dorsal fin with three simple and seven branched rays, last simple ray strong, spinous, weakly serrated posteriorly. Pectoral fin with one simple and 13-15 branched rays, its tip rounded, reaching almost one or two scales anterior to pelvic-fin origin. Pelvic fin with one simple and seven branched rays, 
its tip rounded, not reaching vent. Anal fin with three simple and five branched rays, its distal margin concave. Caudal fin deeply forked, with $6-7+6-7$ principal rays and 8-9+8-9 branched rays.

Lateral line complete. Lateral line originates from opercular joint, rise dorsally till humeral spot, thereafter decreases till vertical from dorsal fin origin, thereafter runs along with intercalated scale row till end of hypural notch. Lateral line with 19-22 scales with last scale on caudal peduncle unpunctuated (i.e., 18-21 pored scales), transverse scales $4-1 / 24$ between dorsal fin origin to lateral line, $2 \frac{1}{2}-3$ between lateral line to pelvic fin base, predorsal scales 8 , prepelvic scales 9, preanal scales 14-15, circumpeduncular scales 12 . Prepelvic axillary scale present, its exposed length about one- third of pelvic fin length.

\section{Osteology}

Osteology of paratype BNHS FWF 79 (female) is shown in Image 3. Post-epiphysial fontanelle absent (Fig. 1a); infraorbital three deep, partially overlapping the cheek and preoperculum (Fig. 1b). Gill rackers simple, acuminate (not branched or laminate), with 3 rackers on epibranchial, one at angle and 14-15 $(n=4)$ on first ceratobranchial. Four predorsal neural spines present. Four supra neurals present. First pterygiophore of dorsal fin inserted between $8^{\text {th }}$ and $9^{\text {th }}$ vertebrae. Weberian apparatus constitutes first four vertebrae. Predorsal vertebrae including weberian apparatus 8 . Total number of vertebrae $4+26$, with $4+13$ abdominal
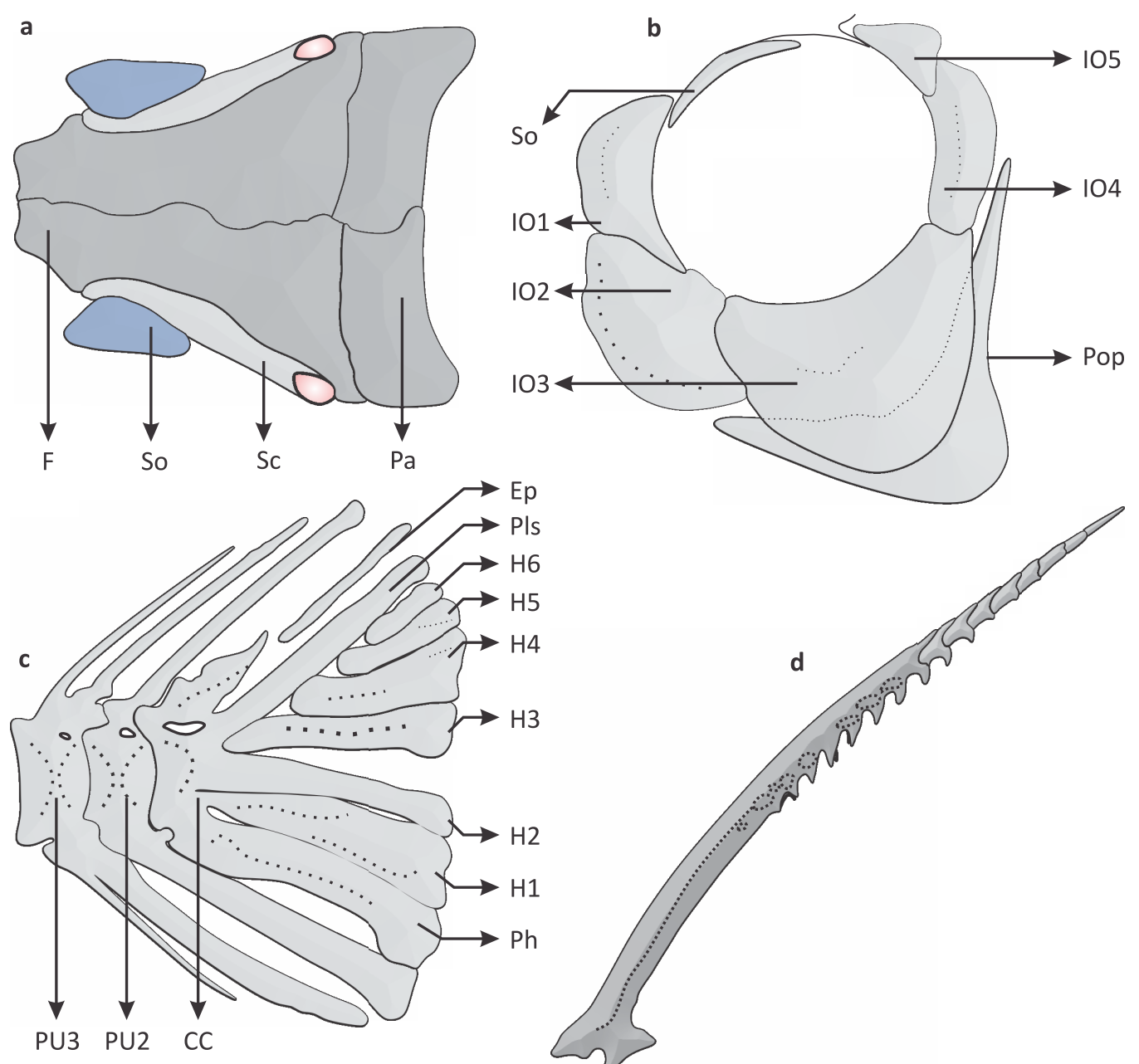

PU3 PU2 CC

\section{$5 \mathrm{~mm}$}

Figure 1. Osteology of Pethia lutea sp. nov.

(a) Dorsal view of orbital region of cranium ( $\mathrm{F}$ - frontal; Pa - parietal; Sc - supraorbital sensory canal); (b) circumorbital series (So - supraorbital; I01-5, infraorbitals 1-5; Pop - preopercle); (c) caudal skeleton (CC - compound centrum; Ep - epural; H1-6, hypurals 1-6; $\mathrm{Ph}$ - parhypural; PIs - pleurostyle; PU2-3, preural centra 2-3) and (d) last unbranched dorsal-fin ray. 


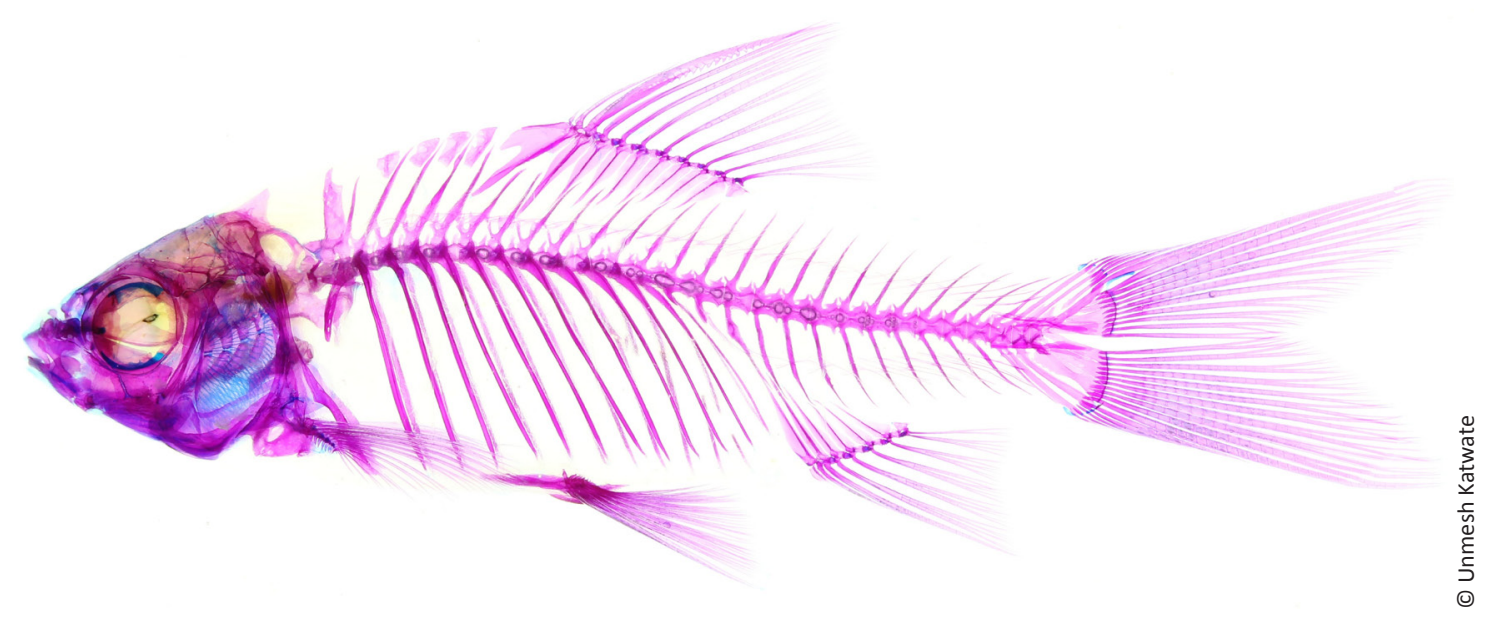

Image 3. Cleared and stained specimen of Pethia lutea sp. nov. (Paratype BNHS FWF 79, female, 34.6mm SL).

and 13 caudal vertebrae. Caudal fin with six hypurals and one parhypural, last three caudal vertebrae support caudal fin, free uroneural absent (Fig. 1c). Last simple ray serrated posteriorly with 6-9 pairs of serrae on distal half of spine, 2-3 serrae on apical half of spine (Fig. 1d).

\section{Coloration}

In life (Image 4): Body bright yellowish with irridescence on scale, each scale bordered with black pigmentation. Body with one humeral spot, sometimes appear like a short vertical band, covers $3^{\text {rd }}$ and $4^{\text {th }}$ lateral line scale, extends to one scale up and down, one caudal blotch encircles caudal peduncle dorsally which covers $17^{\text {th }}-19^{\text {th }}$ lateral line scale. Yellow band encircling caudal blotch anteriorly. Dorsal fin plain, without any bands. Dorsal fin of breeding male red. Pectoral, pelvic and anal fins saffron to red. Caudal fin colorless or saffron to red in breeding male. Dorsal, caudal and anal fins colored at distal margin. Iris pale yellow, with saffron inner and outer edges across upper half of eye. Eyes with middle vertical half black streak. Opercular region studded with minute black and red spots. Infra orbital region studded with black spots (Image 4e).

In preservative (Image 1, 2): Body and fin color patterns fade in preservation except humeral and caudal spots. Body cream colored with dorsolateral portion above lateral line deeply pigmented.

\section{Etymology}

The specific name 'lutea' is Latin for 'yellow' and is named for the characteristic bright yellow colored body in life. Gender feminine.

\section{Common name \\ Citron Barb}

\section{Distribution}

The species is restricted to west flowing river systems in the northern part of the Western Ghats (between 17$19{ }^{\circ} \mathrm{N}$ latitudes) in Maharashtra State, India (Image 5). Currently the species is known from eight localities in six west flowing river systems, viz.,: Ulhas, Kal, Kundalika, Savitri, Jagbudi and Shastri. Extensive surveys have failed to record this species north of Ulhas River system and south of Shastri River system as well as east flowing rivers in the northern parts of Western Ghats.

\section{Habitat}

Habitat at type locality is shown in Image 6. The new species was recorded from riffles and runs with boulders and gravels as substratum. Adult specimens were mostly found to be associated with submerged vegetation. The species was found only in clear unpolluted river stretches with well oxygenated waters and were not observed in pools and ditches. Co-occurring species included those within the genera Salmostoma, Devario, Dawkinsia, Garra, Puntius, Systomus and Anguilla.

\section{Phylogeny}

Model test suggested best fit nucleotide substitution model to be Tamura \& Nei (1993) model with gamma distribution and invariant sites $(\mathrm{TN} 93+\mathrm{G}+\mathrm{I}, \mathrm{BIC}=$ 16146.96, $\operatorname{lnL}=-7217.72, \mathrm{I}=0.43, \mathrm{G}=0.91$ ) for cytb gene as well as for $\mathrm{COI}$ gene $(\mathrm{BIC}=12304.55, \mathrm{InL}=-5222.09$, $\mathrm{I}=0.52, \mathrm{G}=0.91$ ). Pethia lutea $\mathrm{sp}$. nov. was nested within the clade of Pethia (Fig. 2) conforming its generic status. While $P$. lutea sp. nov. was genetically distinct 
from other Pethia species for which genetic data was available (Fig. 2, 3), specimens of $P$. lutea sp. nov. from Sangameshwar (southern most distribution limit) and from Ulhas River at Karjat (northern most distribution limit) were genetically similar to the topotypic material from Kundalika (Fig. 3).

\section{New records of Pethia punctata}

We recorded Pethia punctata from Terekhol River at Madkhol $\left(15.94^{\circ} \mathrm{N} \& 73.91^{\circ} \mathrm{E}\right)$ and Gad River near Bandiwade $\left(16.15^{\circ} \mathrm{N} \& 73.55^{\circ} \mathrm{E}\right)$ thereby extending the distributional range of this species northwards by about $550 \mathrm{~km}$ (Image 7). The identity of the species as $P$. punctata was conformed from morphology (Images 8,9,
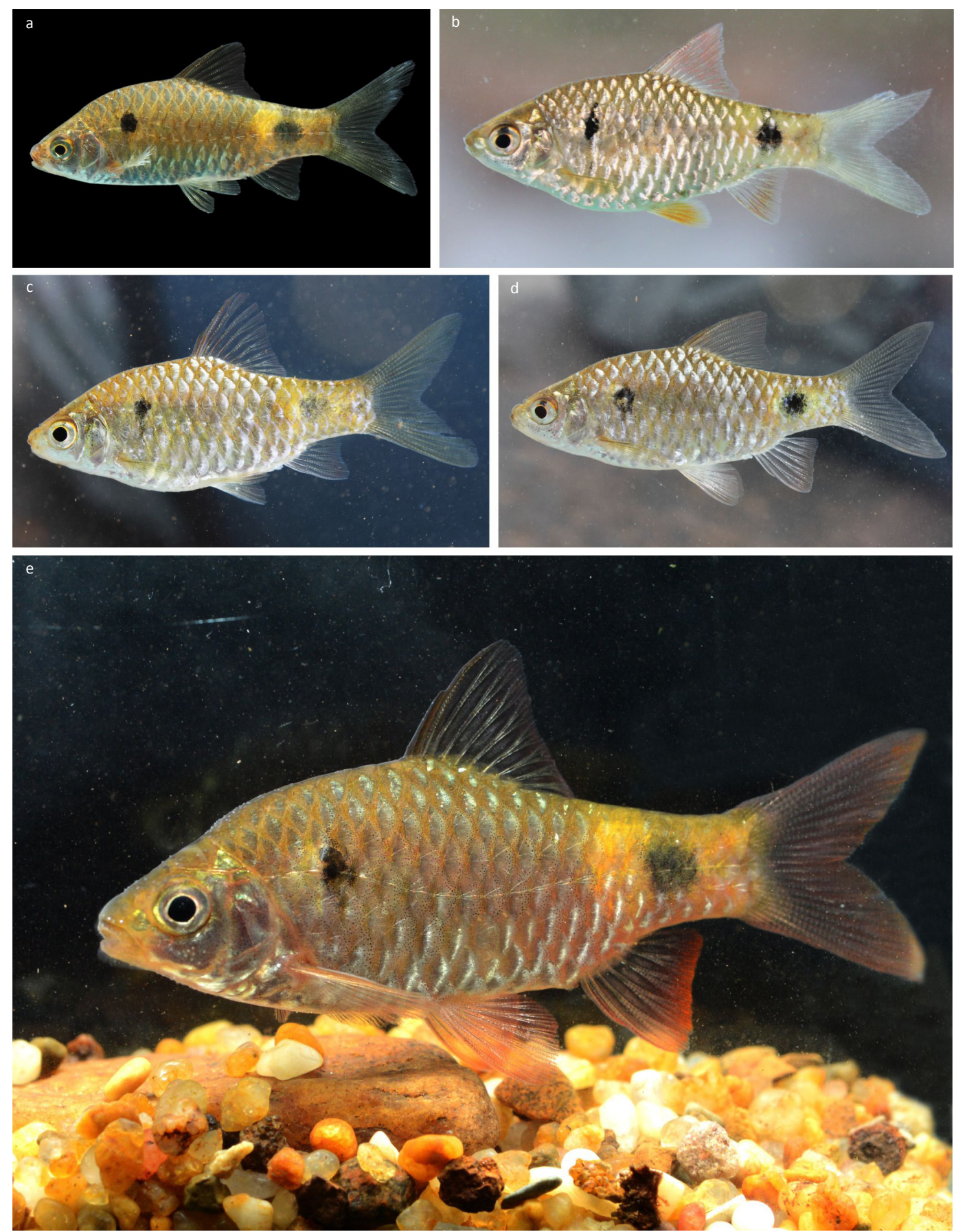

Image 4. Paratypes of Pethia lutea sp. nov. in life.

a - Bhira (WILD-14-PIS-061), b - Mahad (BNHS FWF 75), c - Poladpur (BNHS FWF 83), d - Poladpur (BNHS FWF 84), and e - breeding male from Jagbudi River, Khed (specimen not collected). Photo credit: (a-d) Unmesh Katwate and (e) Ralf Britz. 


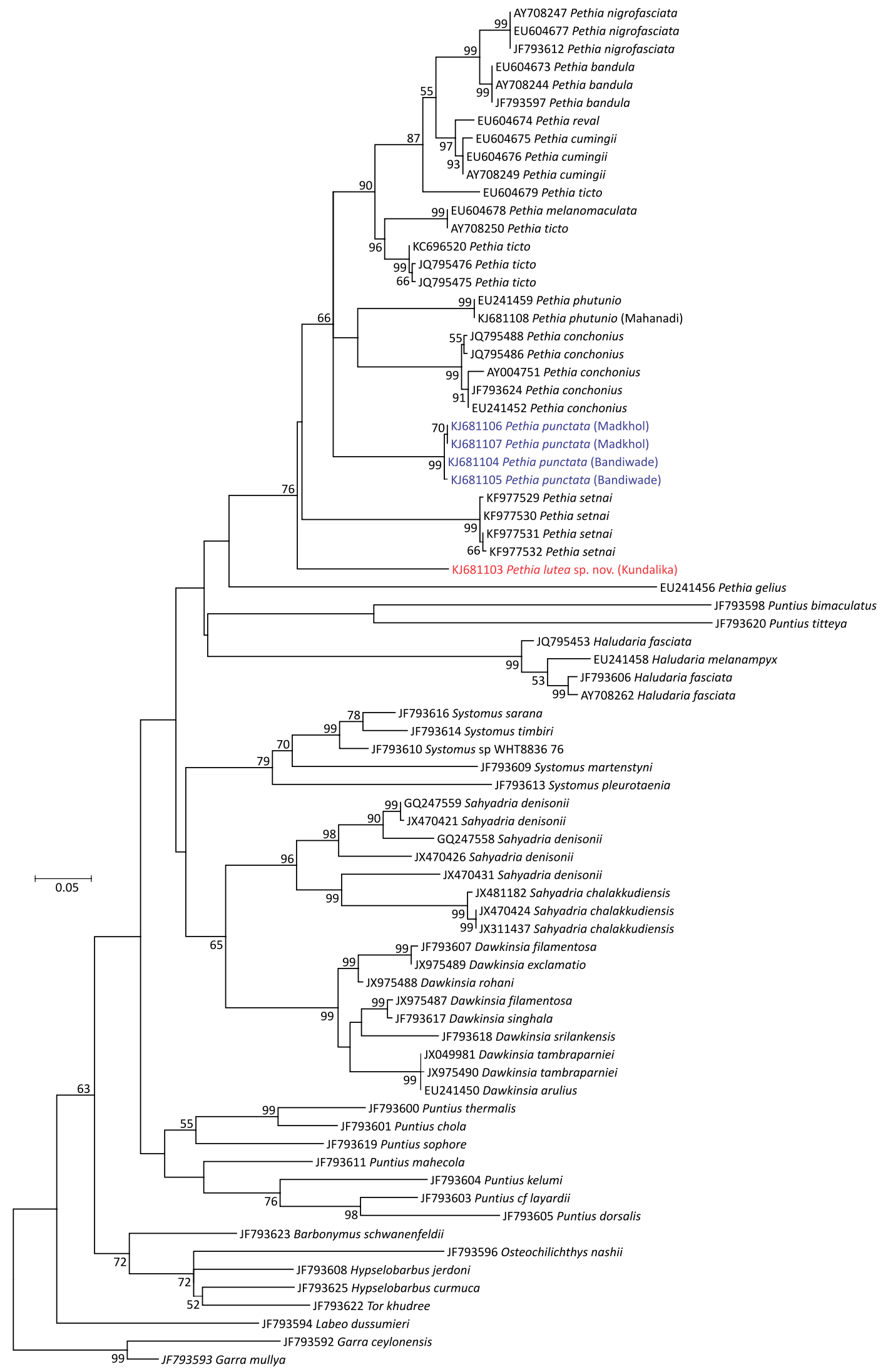

Figure 2. Phylogenetic analysis of Pethia and related genera based on cytb gene sequence. Values at the node are bootstrap values for 1000 iterations. Garra species are used as outgroup. 


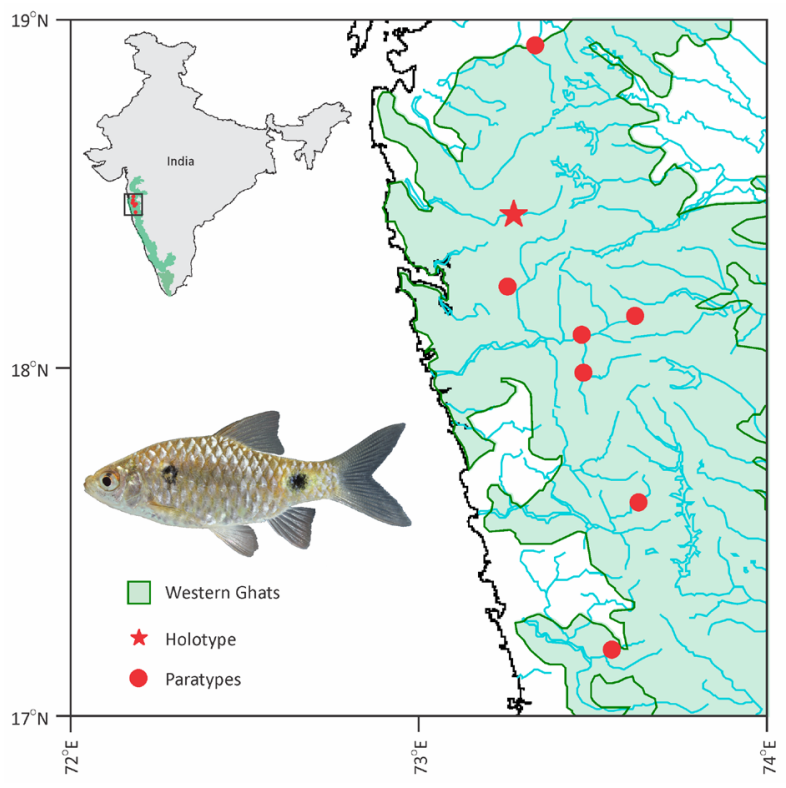

Image 5. Distribution of Pethia lutea sp. nov. in the northern Western Ghats

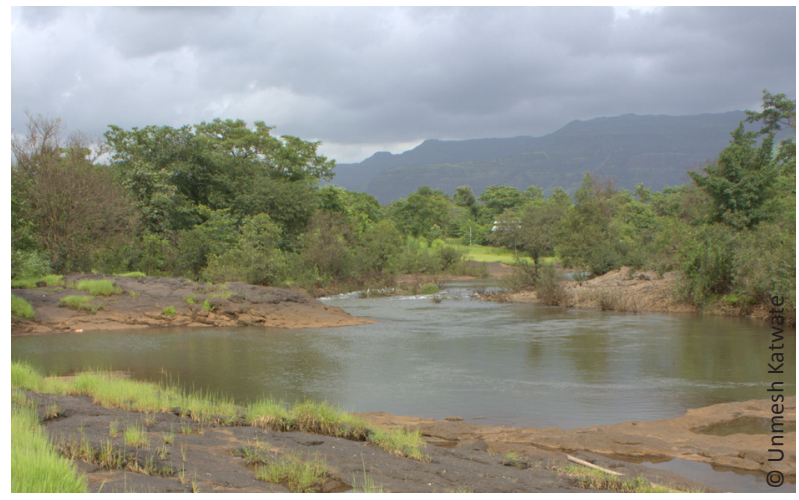

Image 6. Habitat at the type locality of Pethia lutea sp. nov. in Kundalika River.

Table 2) and genetic data (COI gene sequence HE801573) of topotypic material (Fig. 3). Pethia punctata was collected from slowly flowing secondary streams (Image 10) with riparian cover. Stream bed was sandy with gravel and submerged vegetation (Cobomba sp.). Other

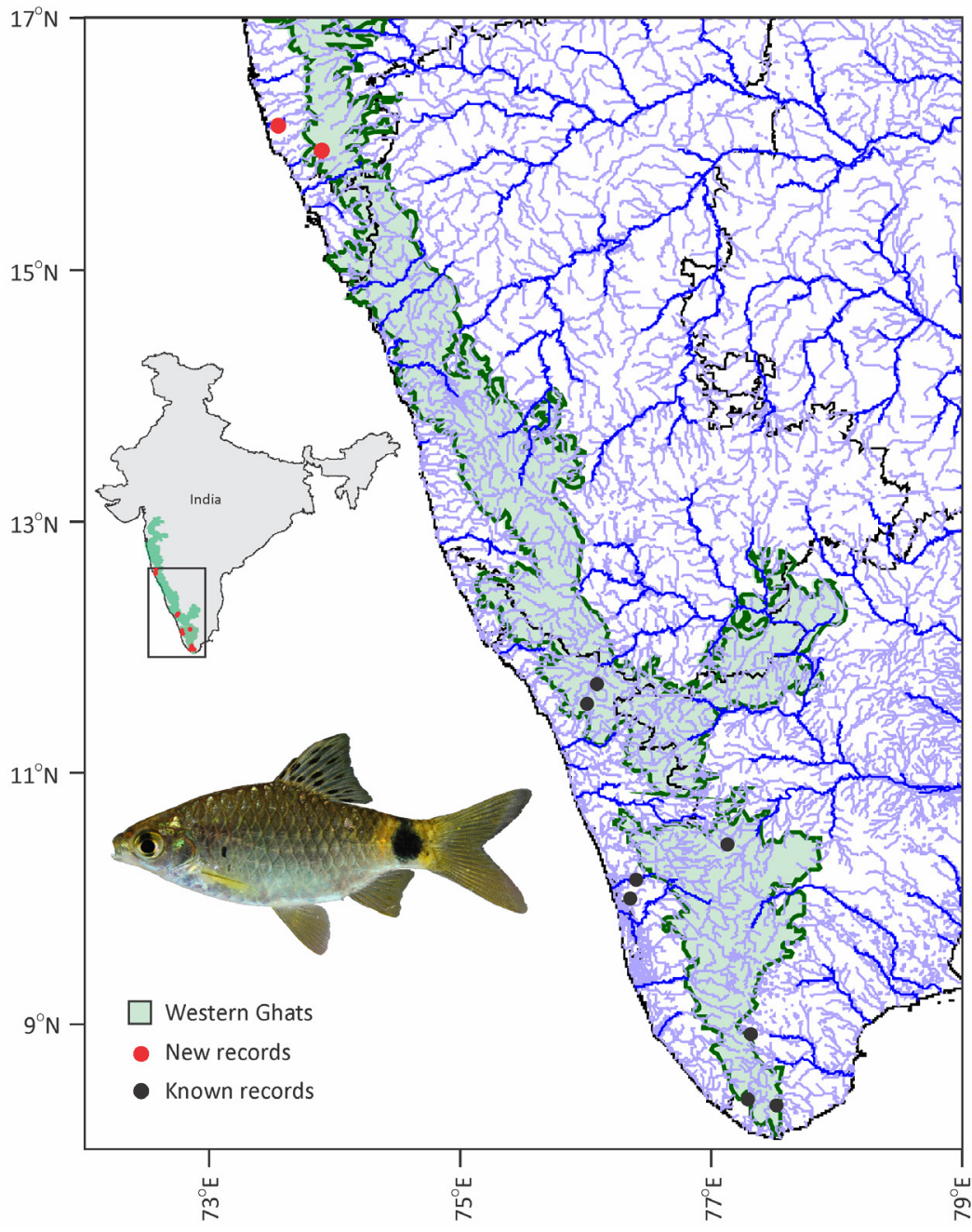

Image 7. Distribution of Pethia punctata In the Western Ghats of India 


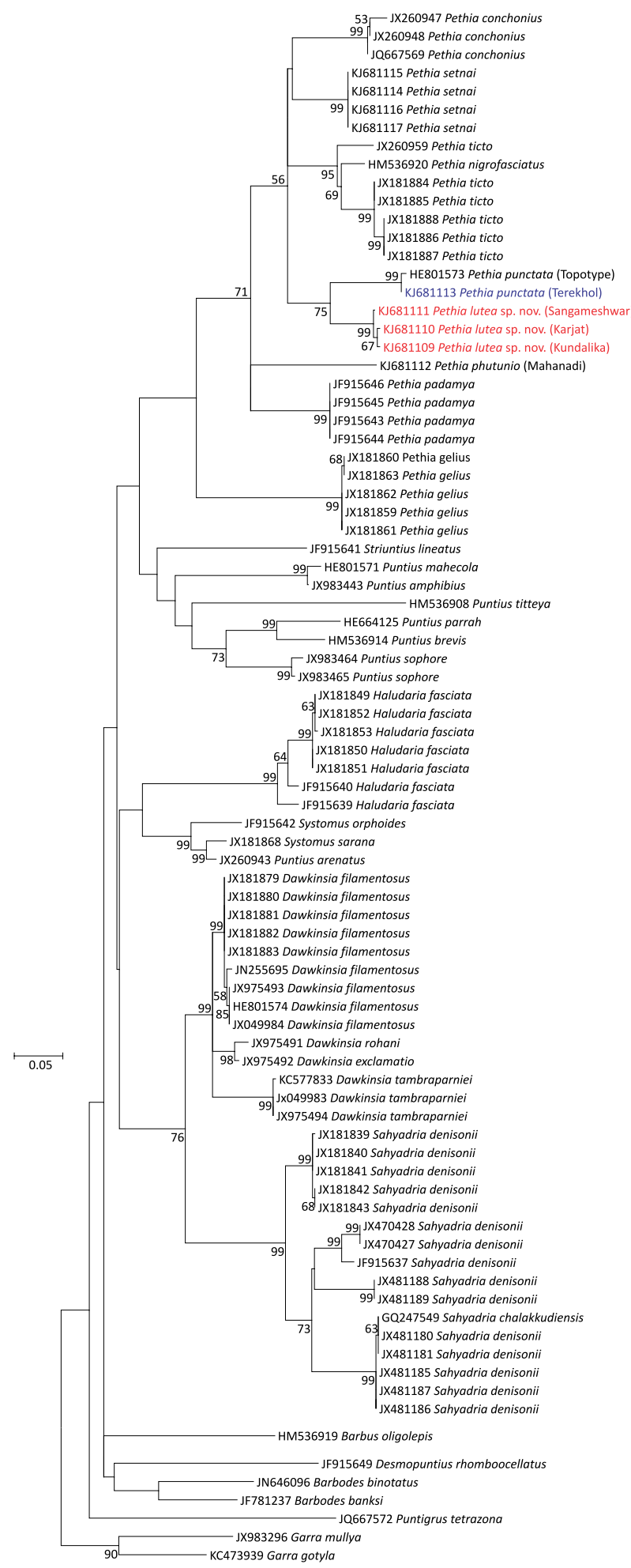

Figure 3. Phylogenetic analysis of genus Pethia based on COI gene sequence. Values at the node are bootstrap values for 1000 iterations. Garra species are used as outgroup. co-occurring species in this locality included those within the genera Horabagrus, Mystus, Aplocheilus, Devario, Rasbora, Puntius, Dawkinsia and Ompok.

One specimen collected from Bandiwade which was cleared and stained (Image 11) showed the following osteological characters: Post-epiphysial fontanelle absent (Fig. 4a); infraorbital 3 moderately deep, partially overlapping the cheek and preoperculum (Fig. 4b). Gill rackers simple, acuminate (not branched or laminate), with 3 rackers on epibranchial, one at angle and 9-10 $(n=2)$ on first ceratobranchial. Four predorsal neural spines present. Four supra neurals present. First pterygiophore of dorsal fin inserted between $8^{\text {th }}$ and $9^{\text {th }}$ vertebrae. Weberian apparatus constitutes first four vertebrae. Predorsal vertebrae including weberian apparatus 8 . Total number of vertebrae $4+25$. Caudal fin with six hypurals and one parhypural, last three caudal vertebrae support caudal fin, paired haemal spines and neural spines on third preural centra, free uroneural absent, last neural spine on compound centrum stunted (Fig. 4c). Last simple ray of dorsal fin strong, spinous, densely serrated posteriorly with 11-14 pairs of serrae $(n=7)$ on distal half of spine, 2 serrae on apical half of spine (Fig. 4d).

\section{DISCUSSION}

Of the 35 valid species of genus Pethia, only seven occur in the river drainages originating in the Western Ghats region, viz.,: P. muvattupuzhaensis (Beevi \& Ramachandran, 2005), P. narayani (Hora, 1937), P. nigripinna (Knight, Rema Devi, Indra \& Arunachalam, 2012), P. pookodensis (Mercy \& Jacob, 2007), P. punctata (Day, 1865), P. setnai (Chhapgar \& Sane, 1992) and $P$. sharmai (Menon \& Devi 1993). Out of these, only four species, $P$. muvattupuzhaensis, $P$. narayani, $P$. punctata and $P$. setnai have complete lateral line, similar to $P$. lutea sp. nov., while the other species have an incomplete lateral line.

Pethia lutea sp. nov. can be distinguished from closely related species that occur in the Western Ghats, having complete lateral line, based on 19-22 pored lateral line scales (vs. 23-24 in P. punctata and 24-25 in $P$. muvattupuzhaensis), 6-9 pair of serrae on distal half of last unbranched ray of dorsal fin (vs. 11-14 in $P$. punctata and 10-16 in $P$. setnai) and 13-15 branched pectoral fin rays (vs. 9-10 in $P$. punctata). Pethia lutea sp. nov. can also be distinguished from $P$. punctata and $P$. setnai in having gill rakers three on epibranchial, one at angle and 14-15 on first ceratobranchial (vs. 
Table 2. Morphometric characters of Pethia punctata collected from Cochin (type locality), Bandiwade and Madkhol. Raw morphometric data is provided in Appendix B.

\begin{tabular}{|c|c|c|c|c|}
\hline \multirow{2}{*}{ Morphometry } & \multicolumn{2}{|c|}{$\begin{array}{l}\text { Topotypic material } \\
\text { from Cochin }(n=3)\end{array}$} & \multicolumn{2}{|c|}{ Bandiwade and Madkhol $(n=7)$} \\
\hline & Mean (sd) & Range & Mean (sd) & Range \\
\hline Total length (mm) & $58.4(4.9)$ & $53.1-62.7$ & $41.4(6.8)$ & $34.2-53.7$ \\
\hline Standard length (SL, mm) & $45.9(4.8)$ & $40.7-50.2$ & $32.1(5.2)$ & $26.3-41.2$ \\
\hline \multicolumn{5}{|l|}{$\% S L$} \\
\hline Head length $(\mathrm{HL})$ & $25.6(1.5)$ & $23.9-26.5$ & $29.8(1.1)$ & $28.5-31.3$ \\
\hline Head depth & $20.0(0.6)$ & $19.4-20.4$ & $22.2(2.2)$ & $18.6-25.8$ \\
\hline Head width & $14.0(0.6)$ & $13.4-14.7$ & $14.7(1.2)$ & $13.8-17.4$ \\
\hline Body depth & $35.5(2.1)$ & $33.2-37.4$ & $38.9(1.2)$ & $37.1-40.5$ \\
\hline Body width at dorsal fin origin & $14.6(0.7)$ & $13.9-15.2$ & $13.8(1.9)$ & $11.5-16.6$ \\
\hline Body width at anal fin origin & $12.1(0.6)$ & $11.6-12.7$ & 10.9 (1.9) & $8.9-14.0$ \\
\hline Pre dorsal distance & $48.6(2.1)$ & $46.7-50.9$ & $52.5(1.6)$ & $51.0-54.8$ \\
\hline Dorsal to hypural distance & $55.2(1.2)$ & $53.9-56.4$ & 48.0 (1.9) & $44.4-50.1$ \\
\hline Prepelvic distance & $48.2(1.1)$ & $47.2-49.4$ & $50.6(1.1)$ & $49.3-52.2$ \\
\hline Preanal distance & $72.0(1.4)$ & $70.4-73.1$ & $73.0(2.0)$ & $69.3-75.1$ \\
\hline Prepectoral distance & $26.7(0.7)$ & $26.0-27.3$ & $30.0(1.4)$ & $28.3-31.8$ \\
\hline Dorsal fin length & $26.4(1.6)$ & $24.7-27.6$ & $28.6(1.9)$ & $25.8-31.8$ \\
\hline Dorsal fin spine length & - & - & $21.1(2.6)$ & $18.1-24.7$ \\
\hline Length of dorsal fin base & $18.4(0.3)$ & $18.0-18.7$ & $15.7(1.0)$ & $13.9-16.9$ \\
\hline Pectoral fin length & $20.0(0.4)$ & $19.7-20.3$ & $19.7(1.5)$ & $17.4-21.5$ \\
\hline Anal fin depth & $16.9(2.1)$ & $15.4-19.4$ & $17.2(1.1)$ & $16.3-18.9$ \\
\hline Caudal peduncle length & $19.7(1.6)$ & $18.2-21.5$ & $18.0(1.2)$ & $17.0-20.0$ \\
\hline Caudal peduncle depth & $14.3(0.6)$ & $13.8-15.0$ & $15.0(0.5)$ & $14.4-16.1$ \\
\hline \multicolumn{5}{|l|}{$\% \mathrm{HL}$} \\
\hline Head depth & $78.5(2.3)$ & $76.9-81.1$ & 74.4 (7.9) & $64.0-88.8$ \\
\hline Head width & $54.8(3.8)$ & $50.6-58.1$ & $49.3(4.9)$ & $44.1-59.8$ \\
\hline Snout length & $31.7(4.1)$ & $28.4-36.3$ & $27.3(2.2)$ & $24.1-30.5$ \\
\hline Eye diameter & $31(1.4)$ & $29.9-32.6$ & $31.8(2.8)$ & $28.2-35.2$ \\
\hline Inter orbital width & $33.3(0.9)$ & $32.4-34.1$ & $35.1(3.3)$ & $33.2-42.6$ \\
\hline \multicolumn{5}{|l|}{ Meristics } \\
\hline Lateral line scale & & 24 & & $23-24$ \\
\hline Transverse scale rows & & $1 / 24 / 1 / 31 / 2$ & & $1 / 24 / 1 / 3^{1} / 2$ \\
\hline Predorsal scale & & 8 & & 8 \\
\hline Prepelvic scle & & - & & 9 \\
\hline Preanal scale & & - & & $14-15$ \\
\hline Circumpeduncular scales & & - & & 12 \\
\hline DF ray & & iii 8 & & iii 8 \\
\hline Pectoral fin ray & & i 9-10 & & i 9-10 \\
\hline Pelvic fin ray & & i 7 & & i 7 \\
\hline Anal fin ray & & iii 5 & & iii 5 \\
\hline Caudal fin ray (principal) & & - & & $6-7+6-7$ \\
\hline Caudal fin rays (branched) & & - & & $9+8$ \\
\hline
\end{tabular}



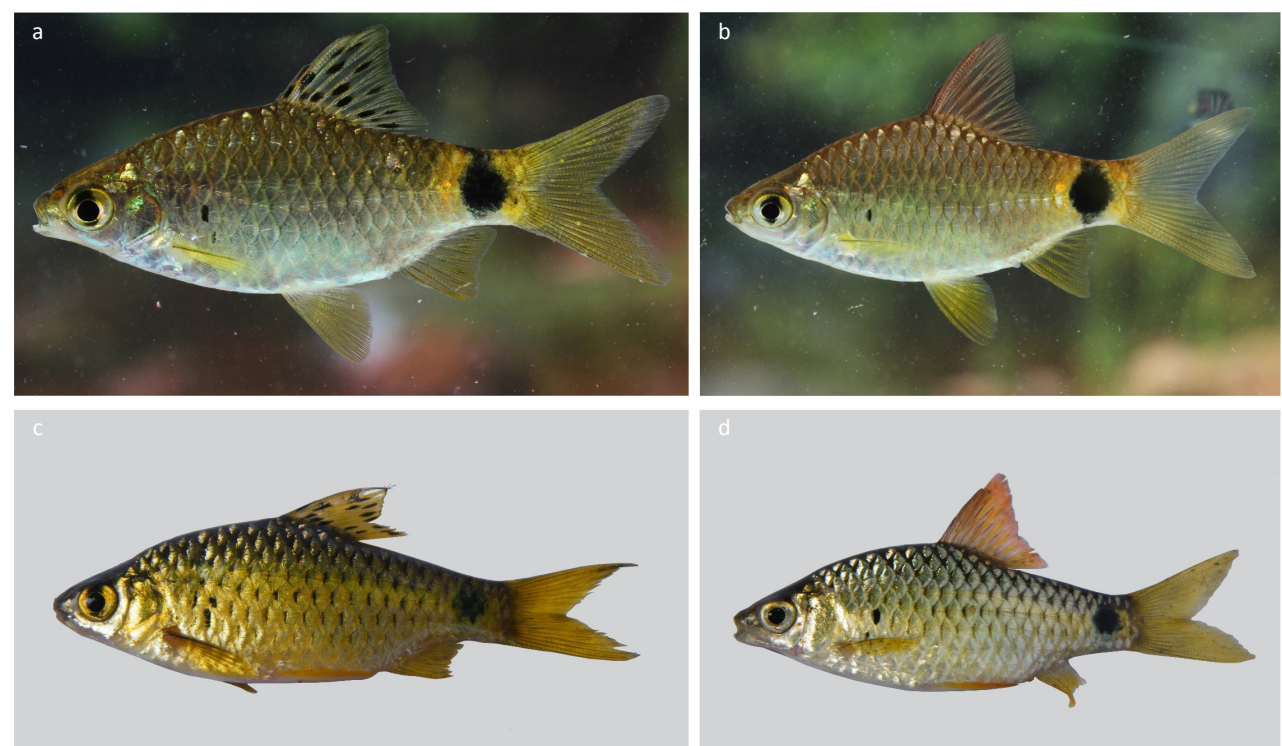

Image 8. Pethia punctata. Photo credit: (a-b) Unmesh Katwate, (c-d) Rajeev Raghavan

a - male and b - female in life from Bandiwade, Gad River. c - male and d - female freshly collected specimens from Pampa River, Kerala.

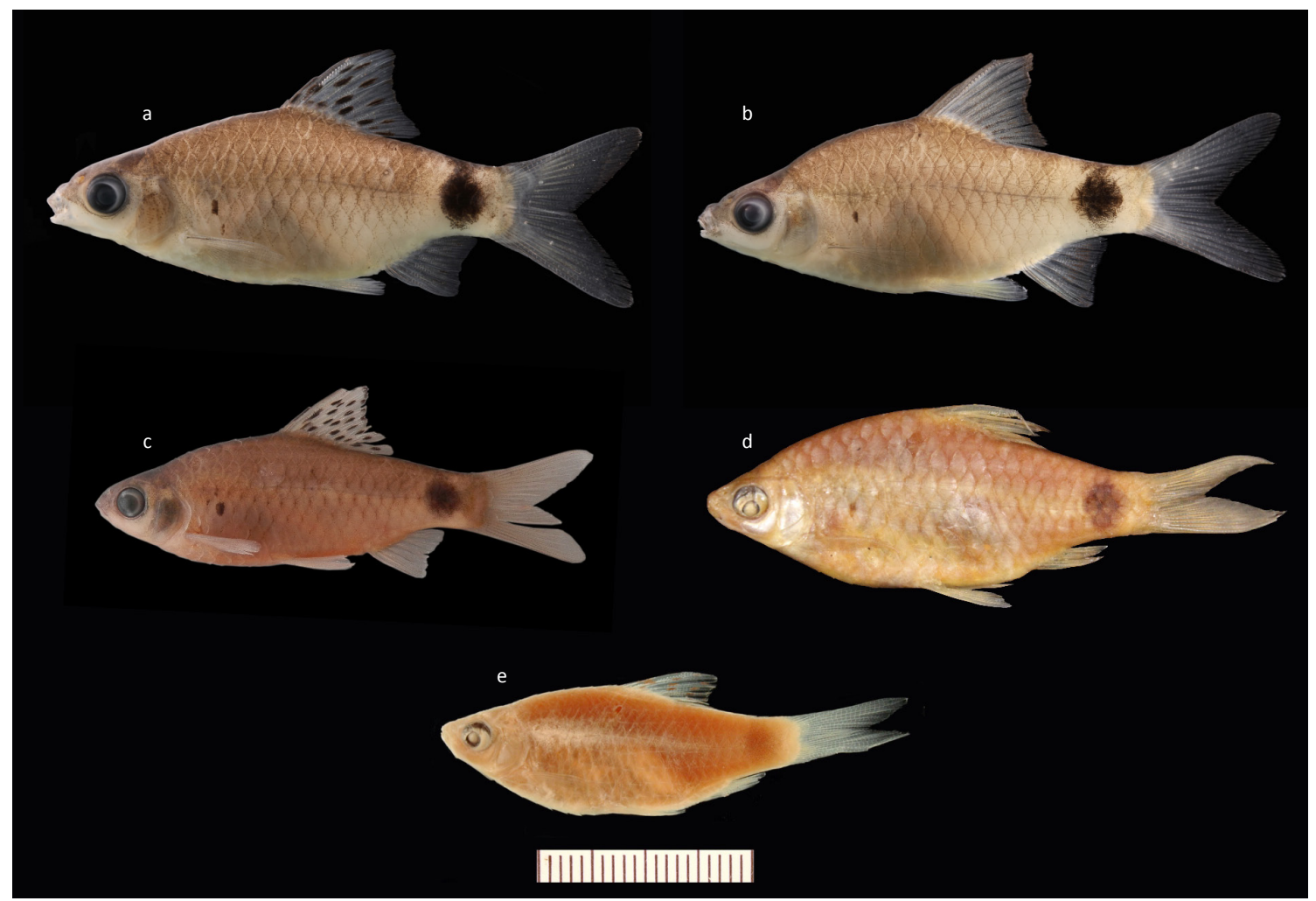

Image 9. Pethia punctata preserved specimens.

a - male and b - female from Bandiwade, Gad River, c - male from Pampa River, Kerala, d - Day's material BMNH 1889.2.1.755, and e - Day's material MCZ 4303. Photo credit: (a-b) Unmesh Katwate, (c) Neelesh Dahanukar, (d) Rajeev Raghavan and (e) President and Fellows of Harvard College, Museum of Comparative Zoology, Harvard University.

three on epibranchial, one at angle and 8-9 on first ceratobranchial in $P$. punctata) and infraorbital three much deep and enlarged (vs. considerable small and shallow in P. punctata and P. setnai). Pethia lutea sp. nov. has a distinctly different color pattern with a large humeral spot covering $3^{\text {rd }}$ to $4^{\text {th }}$ lateral line scale which 


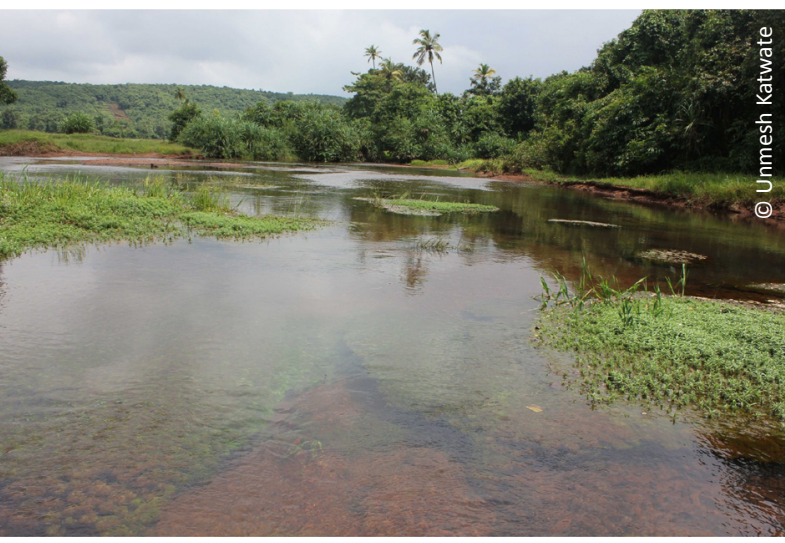

Image 10. Habitat of Pethia punctata at Bandiwade, Gad River.

spread over one scale above and below the lateral line (vs. small humeral spot on $4^{\text {th }}-5^{\text {th }}$ scale below the lateral line in $P$. punctata and $P$. muvattupuzhaensis and a

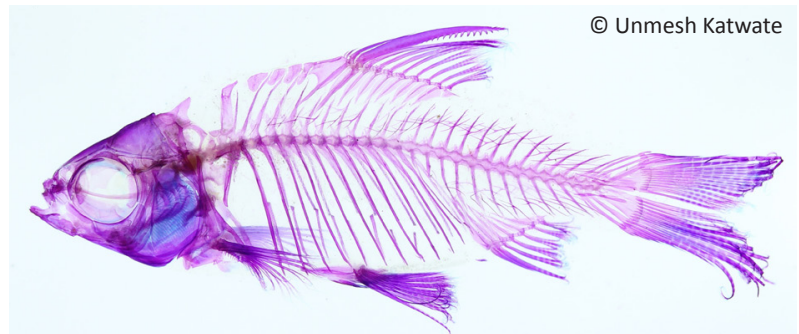

Image 11. Cleared and stained specimen of Pethia punctata (BNHS FWF 88, female, 29.1mm SL).

dorsolateral vertical band covering $3^{\text {rd }}$ and $4^{\text {th }}$ lateral line scales and scales above them in $P$. setnai) and a caudal blotch covering $17^{\text {th }}$ to $19^{\text {th }}$ lateral line scales (vs. $19^{\text {th }}$ to $21^{\text {st }}$ in $P$. punctata and $P$. muvattupuzhaensis and a vertical transverse band on $16^{\text {th }}$ to $18^{\text {th }}$ lateral line scales and scales above and below them in P. setnai). Pethia

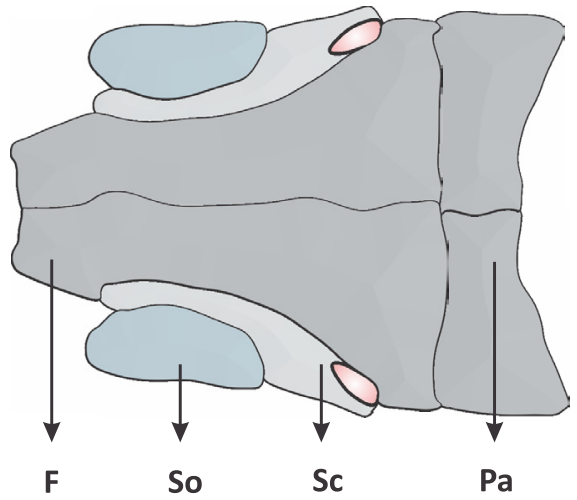

$\mathbf{F}$
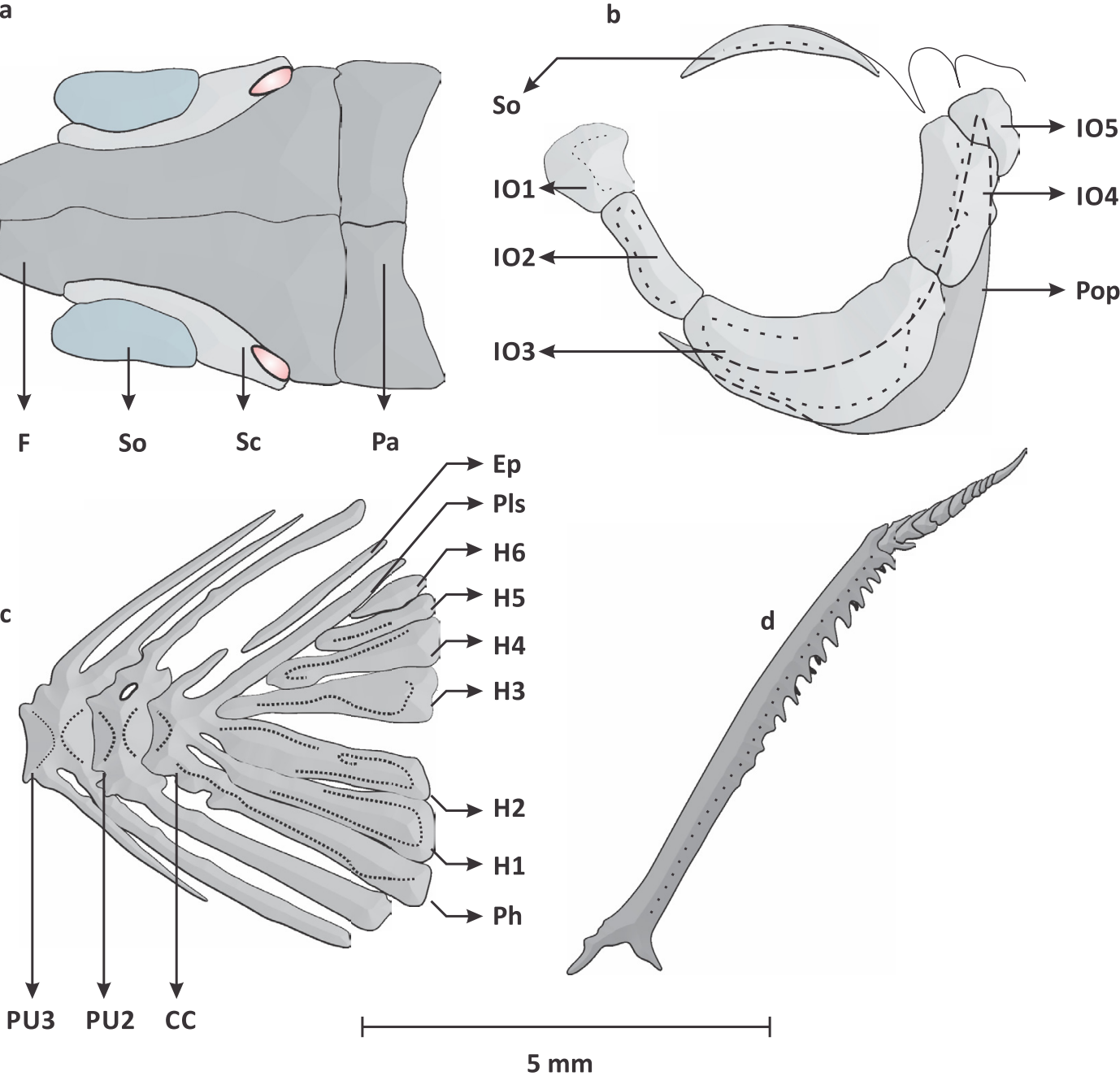

Figure 4. Osteologyof Pethia punctata. Abbreviations as per Figure 1. 
setnai also have a middle grey band below the dorsal fin (vs. absent in P. lutea sp. nov.) have distinct eye color pattern in comparison with $P$. punctata and $P$. setnai (Fig. 5). The iris of Pethia lutea sp. nov. is iridescent yellowish in color with saffron edges and dark mid streak spread only in upper half of the eye vs. iris dark yellow in color having mid vertical streak completely spread across mid of the eye in P. punctata and iris silver in color with yellow hallow around the pupil and radial half streak on the upper half of the iris in P. setnai (Fig. 5). Pethia lutea sp. nov. differs from $P$. narayani by two most prominent characters of having last unbranched ray string and serrated (vs. feeble, articulated and smooth) and dorsal fin with 8 branched rays (vs. 9 branched fin rays).

Pethia lutea sp. nov. is distinguished from other closely related taxa within the Western Ghats by having complete lateral line (vs. incomplete lateral line in $P$. pookodensis and $P$. nigripinna), number of lateral transverse scale rows, $2 \frac{1}{2}-3$ between lateral-line scale row and ventral fin origin (vs. $3 \frac{1}{2}$ in $P$. pookodensis), seven branched pelvic fin rays (vs. 8 in $P$. pookodensis) and gill rakers 14-15 on first ceratobranchial (vs. 6 in $P$. pookodensis and 5-6 in P. nigripinna). The location of humeral spot and caudal blotch also distinguishes $P$. lutea sp. nov. from $P$. pookodensis and $P$. nigripinna. A humeral spot, more like a vertical band covers $3^{\text {rd }}-4^{\text {th }}$ lateral line scale which spreads across one scale above and below the lateral line in $P$. lutea sp. nov. (vs. small on $3^{\text {rd }}-4^{\text {th }}$ scale of lateral line in $P$. pookodensis and $P$. nigripinna), second large spot on caudal peduncle appears more like a band and covers $17^{\text {th }}-19^{\text {th }}$ scale of lateral line and encircles caudal peduncle dorsally (vs. two spot on caudal peduncle in $P$. pookodensis, initial covers $16^{\text {th }}-17^{\text {th }}$ lateral line scale and later on $19^{\text {th }}$ $20^{\text {th }}$ scale of lateral line whereas a large caudal spot appears like a band on $18^{\text {th }}-19^{\text {th }}$ scale of lateral line in $P$. nigripinna), body bright yellowish in color with iridescence on scale (vs. body iridescent silver in $P$. pookodensis, adult male generally have deep red body color) and dorsal, pectoral, ventral and anal fins saffron to red in adult male (vs. pale yellow in $P$. pookodensis and black in $P$. nigripinna).

Pethia ticto was considered as a widely distributed species occurring throughout India, Sri Lanka and Myanmar by Hora et al. (1939). However, the wide variation in the morphological characters from different populations of $P$. ticto studied by Hora et al. (1939) suggests that the different populations might represent several distinct species. We, therefore, consider only the data of $P$. ticto collected from Ranigunge (West Bengal) by Hora et al. (1939) as it is the closest population from
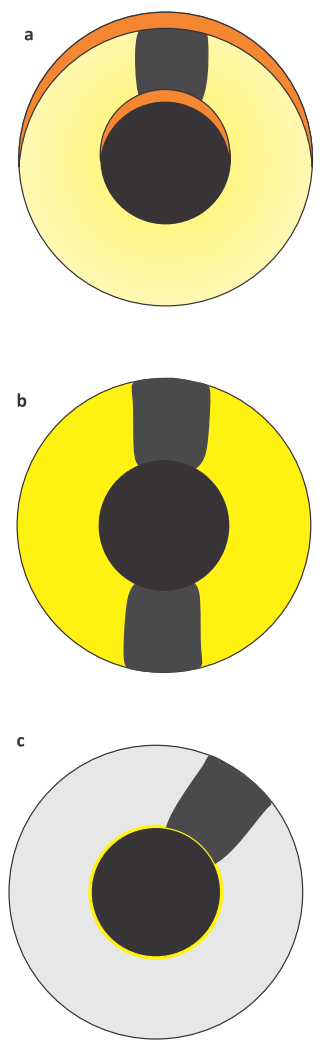

Figure 5. Diagrammatic representation of live color pattern of eyes in male specimens of (a) Pethia lutea sp. nov., (b) P. punctata and (c) P. setnai.

the type locality of the species namely 'southeastern parts of Bengal' (Hamilton 1822, p. 314). Pethia lutea sp. nov. differs from $P$. ticto from Ranigunge (Hora et al. 1939) in having a complete lateral line (vs. incomplete), presence of humeral and caudal spots (vs. absence) and 8 predorsal scales (vs. 9-11). Description of $P$. ticto by Linthoingambi \& Vishwanath (2007) is based on the collections from Bramhaputra River system from Assam, Nagaland and Manipur, which again is not from the type locality of the species. However, $P$. lutea sp. nov. differs from $P$. ticto description by Linthoingambi \& Vishwanath (2007) in having complete lateral line (vs. incomplete), 8 predorsal scales (vs. 9-10), transverse scale count $4-4 \frac{1}{2} / 1 / 2 \frac{1}{2}-3$ (vs. $5 \frac{1}{2} / 1 / 51 / 2$ ) and dorsal fin plain (vs. dorsal fin with two rows of black bands). Although the original description of $P$. ticto is not in details, $P$. lutea sp. nov. differs from the original description of $P$. ticto based on two very prominent characters, first presence of complete lateral line (vs. lateral line is scarcely distinguishable) and second, absence of any bands on the dorsal fin in both sexes (vs. spotted dorsal fin) (Hamilton 1822). Furthermore, P. lutea sp. nov. is genetically distinct (Figure 2 ) from $P$. ticto collected from 
near its type locality in West Bengal $\left(26.85^{\circ} \mathrm{N} \& 80.95^{\circ} \mathrm{E}\right)$ with a raw distance of $13.7 \pm 2.4 \%$ from JQ795475 and $13.7 \pm 2.2 \%$ from JQ795476 in cytb gene sequence.

Species similar to Pethia ticto appear in the literature by Hamilton (1822) and McClelland (1839) and taxonomic validity of these names need to be clarified. In the original description of Cyprinus titius (now a synonym of Puntius chola), Hamilton (1822) referred to 'Cyprinus tictis' from north-east parts of Bengal, a species similar to but differing from Pethia ticto. Hamilton (1822) mentions ".... I took no notes, and, therefore, until I recover the drawings, I cannot give this fish a specific character, although I call it Tictis". Since this species has not been described and has no diagnostic characters we consider 'Cyprinus tictis' as a nomen nudum. Similarly, McClelland (1839) in his description of Pethia ticto, refers to a species 'Cyprinus bimaculatus' based on drawings of Hamilton. However, he suggested that '..as it has two black spots on each side, it should rather have been named quadrimaculatus'. Neither 'Cyprinus bimaculatus' nor 'Cyprinus quadrimaculatus' has any description or diagnostic characters or type localities. As a result, we consider both 'Cyprinus bimaculatus' and 'Cyprinus quadrimaculatus' also as nomina nuda.

Pethia stoliczkana, which also has a complete lateral line, was described from Eastern Myanmar by Day (1871). Pethia lutea sp. nov. differs from P. stoliczkana based on the original description in having 19-22 scales along the lateral line (vs.25) (Day 1871). Linthoingambi \& Vishwanath (2007) provided description on $P$. stoliczkana from Chindwin basin, which matches largely with the original description except in transverse scale count between lateral line and ventral fin origin. While, Linthoingambi \& Vishwanath (2007) provide a value of 51/2, Day's (1871) original description mentions $3 \frac{1}{2}$. However, it is essential to note that in the same communication Day (1871) mentions transverse scale count as 5/6, (i.e., 6 scales between lateral line and pelvic fin base), which is a contradiction. Therefore, $P$. stoliczkana studied by Linthoingambi \& Vishwanath (2007) is likely to be conspecific with $P$. stoliczkana sunso stricto. Pethia lutea sp. nov. differs from $P$. stoliczkana studied by Linthoingambi \& Vishwanath (2007) in having $1 / 24 / 1 / 2 \frac{1}{2}-3$ transverse scale count (vs. $1 / 25 / 1 / 5 \frac{1}{2}$ ), first pterygiophore of dorsal fin inserted between $7^{\text {th }}$ and $8^{\text {th }}$ vertebra (vs. between $8^{\text {th }}$ and $9^{\text {th }}$ vertebra) and no bands on dorsal fin (vs. two dark bands on dorsal fin).

Jerdon (1849) described Systomus tripunctatus from the coast of Canara (= southern Karnataka). Current taxonomic status of $S$. tripunctatus is uncertain because of the vague original description. Pethia lutea sp. nov. can however be distinguished from S. tripunctatus based on the distinct color pattern in the two species. Jerdon (1849) mentions three spots over the body, two black spots under end of the dorsal and one at the base of the tail, a color pattern which is drastically distinct from that of $P$. lutea sp. nov.

Pethia lutea sp. nov. can be easily distinguished from all other Indian congeners from Ganga-Brahmaputra and Chindwin-Irrawaddy, drainages as well as other rivers in Myanmar, except $P$. macrogramma (Kullander, 2008), $P$. tiantian (Kullander \& Fang, 2005), P. expletiforis Dishma \& Vishwanath, 2013 and P. guganio (Hamilton, 1822), by having a complete lateral line (vs. incomplete lateral line). Pethia lutea sp. nov. differs from $P$. expletiforis by having eight predorsal scales (vs. 9 predorsal) and presence of vertical humeral spot (vs. absence of humeral spot); from $P$. guganio by having less number of scales (19-22 in lateral series vs. greater number of scales, 29-30) and less number of scales in transverse row (4-1/24/1/21/2-3 vs. $1 / 25 / 1 / 4)$; from $P$. macrogramma by a more wide spread vertical humeral spot on $3^{\text {rd }}-4^{\text {th }}$ lateral line scale (vs. very small or negligible on $3^{\text {rd }}$ scale of lateral line) and less number of transverse row scale $4-1 / 24 / 1 / 2 \frac{1}{2}-3$ (vs. greater number of scales in transverse row $\left.1 / 24 / 1 / 4 \frac{1}{2}\right)$; from $P$. tiantian by having less number of principle $(6-7+6-7)$ and more number of branched $(8-9+8)$ caudal fin rays (vs. more number of principle $(9-10+9)$ and less number of branched $(4-6+5)$ caudal fin rays).

Pethia lutea sp. nov. also differs from its close Sri Lankan congeners, P. nigrofasciata (Günther, 1868), which also has a complete lateral line, by having two spots on flank, one humeral spot and one caudal (vs. three vertical bands on body), more number of prepelvic (9-10) and preanal scales (14-15) (vs. 5-6 prepelvic and 11 preanal scales), interorbital 3 deep and more wide (vs. relatively small interorbital 3); dorsal, pectoral, pelvic and anal fins saffron in color, body yellowish (vs. smoky grey fins and body crimson red and black). Pethia lutea sp. nov. is also genetically distinct from $P$. melanomaculata (Deraniyagala, 1956) (Fig. 2) by a raw distance of $15.3 \pm 2.4 \%$.

Recently, Knight (2013) placed Puntius sharmai Menon \& Devi, 1992 within the genus Pethia. However, in our opinion $P$. sharmai is less likely to be congeneric with Pethia and warrants further studies to understand its exact systematic position. Two other species, Puntius deccanensis Yazdani \& Rao, 1976 and Puntius fraseri Hora \& Misra, 1938, which also possess more than 42 lateral series scales, serrated last unbranched dorsal fin ray and pair of maxillary barbels similar to $P$. sharmai, 
are less likely to belong to genus Pethia. Based on the same characters, Pethia lutea sp. nov. differs greatly from Puntius deccanensis and Puntius fraseri, which are also from the northern part of the Western Ghats.

Pethia lutea sp. nov. is restricted in distribution to the west flowing river systems of the northern part of Western Ghats (between 17-19 ${ }^{\circ} \mathrm{N}$ latitudes) in Maharashtra State, India and extensive surveys have failed to record the species south of $17^{\circ} \mathrm{N}$ latitude and north of $19^{\circ} \mathrm{N}$ latitude as well as east flowing rivers of the region. As a result, the expected extent of occurrence (EOO) is roughly $6000 \mathrm{~km}^{2}$ and area of occupancy (AOO) is less than $200 \mathrm{~km}^{2}$. The species was found only in fast flowing and clear and unpolluted river stretches, and even after extensive surveys was not found in polluted waters, especially near industrial zones near Mahad and Roha. Therefore, increasing urbanization and industrialization in this area are likely to affect the populations of this species adversely. Frequent mass fish kills were observed near Mahad and Roha (U. Katwate, pers. obv. 2010-2013) during the premonsoon period mainly because of heavy discharge of industrial effluents. Further, in several locations, including Shivathar Ghal, Walan Kond and Mahad on Savatri River System and Bhira on Kundalika River, the habitat of this species is also modified by extensive sand mining. As the species prefers flowing waters, presence of established and proposed irrigation and hydroelectric projects, that cut the flow of water and create semilacustrine conditions, could be a plausible threat to the species. Based on these observations we propose a draft IUCN Redlist status for this species as 'Endangered' (Box 1). Fortunately, at least one of the populations from Walan Kond (Savitri River system) is protected through a community sanctuary maintained by local indigenous communities (Katwate et al. 2014).

In this study, we also extend the range of Pethia punctata by a distance of $\sim 550 \mathrm{~km}$. Pethia punctata was described by Day (1865) as Puntius punctatus from the erstwhile Princely State of Cochin, Kerala, India. The generic status of the species was later changed to Barbus (Day 1889). Hora et al. (1939) synonymized Puntius punctatus to Puntius ticto. However, Silas (1952) considered the species to be a valid subspecies $P$. ticto punctatus. Even though Talwar \& Jhingran (1991) and Jayaram (1991) considered Puntius punctatus as a synonym of Puntius ticto; Menon (1999) and Devi et al. (2007) considered Puntius punctatus as a valid species. Recently Pethiyagoda et al. (2012) revised the generic status of the species to Pethia.

Pethia punctata is currently known from west and

\section{Box 1. Proposed IUCN Redlist assessment for Pethia lutea}

Proposed Status: ENGANGERED (EN) B2ab(iii)

Justification: Pethia lutea is assessed as Endangered because of its restricted distribution to the west flowing rivers of northern Western Ghats (between $17^{\circ} \mathrm{N}$ and $19^{\circ} \mathrm{N}$ latitudes in Raigad and Ratnagiri districts of Maharashtra, India), fragmented populations and ongoing threats to its habitats. Currently, the species is known from eight isolated locations from six river systems with an extent of occurrence (EOO) of $6,000 \mathrm{~km}^{2}$. However, in each of the river systems, the species is restricted to, at the most, a $2-\mathrm{km}$ stretch. Since the width of the river does not exceed $50 \mathrm{~m}$, the estimated area of occupancy (AOO) is not more than $200 \mathrm{~km}^{2}$. The species appears to be sensitive to pollution as extensive surveys have failed to record the species from polluted stretches of the rivers; several populations are threatened by habitat alterations as a result of organic and inorganic pollution from industrial and urban wastes. In several locations, the habitats of this species are threatened by extensive sand mining. Because the species prefers fast flowing waters, presence of established and proposed irrigation and hydroelectric dams, which cut the flow of water and reduce the speed of water creating semi-lacustrine conditions, are serious threats to the species.

east flowing rivers in the southern part of Western Ghats in Karnataka, Kerala and Tamil Nadu from Mangai Malai Kulasekaram, Kanyakumari Wildlife Sanctuary and west flowing rivers of Kanyakumari District; Mathalamparai, Tirunelveli District; Pookode Lake and parts of Wayanad; Chalakkudy, Muvattupuzha and Periyar rivers of Ernakulam District; and the Indira Gandhi Wildlife Sanctuary in the Anamalai Hills of Tamil Nadu (Shaji \& Easa 1995; Devi et al. 2005, 2007; Beevi \& Ramachandran 2009; Johnson \& Arunachalam 2009; Knight et al. 2012). Although the species has also been reported from the east flowing Mula-Mutha River of Pune (Tonapi \& Mulherkar 1963), this record has been considered doubtful (Dahanukar 2011) as the species was neither reported by earlier (Fraser 1942; Suter 1944) nor later researchers (Kharat et al. 2001; Wagh \& Ghate 2003) in spite of extensive surveys. Similarly, the report of the species from Sri Lanka (Menon 1999) also needs taxonomic confirmation (Dahanukar 2011).

Our record of Pethia punctata, backed up with morphological and genetic data, suggests that the species is also present in west flowing rivers of southern Maharashtra, namely Terekhol and Gad. This extends the distributional range of the species by about $550 \mathrm{~km}$ in the northern Western Ghats as the previous northernmost record was from Wyanad in Kerala by Shaji \& Easa (1995). Although, the species is known from both west flowing and east flowing rivers of the southern Western Ghats, there is a need for validating 
the reports from east flowing rivers, preferably using genetic analysis. Pethia punctata is currently assessed as 'Least Concern' in the IUCN Red List of Threatened Species (Dahanukar 2011); however, the populations of $P$. punctata in the localities from where collections were made as part of this study are threatened by inflow of sewage water and tourism-related pollution. Further, the area is also subjected to riparian deforestation for mango and cashew plantations. Populations of the species downstream of rocky outcrops in Bandiwade are threatened by siltation and habitat degradation by laterite quarrying.

The northern Western Ghats of India are relatively less explored in terms of their fish diversity and distribution and this is especially true for the west flowing rivers in the Konkan region (Dahanukar et al. 2011; Katwate et al. 2012). The description of Pethia lutea sp. nov. and range extension of $P$. punctata points out that the northern Western Ghats of India is subject to both the Wallacean (incomplete information regarding the distribution of species) and Linnean (many species still not formally described) shortfalls (Bini et al. 2006). The fact that the populations of Pethia lutea sp. nov. are also highly threatened further suggests that there is an immediate need to focus our attention towards conservation of freshwater ecosystems and biota of this region. Because no conservation action plan will be possible in the absence of information on diversity and distribution of species, our study suggests that further detailed studies on the taxonomy, distribution and threats to the habitats and taxa should be encouraged.

\section{Comparative material}

Pethia punctata ( $\mathrm{n}=11)$ : Day's material (syntype?), 1 ex., MCZ 4303, Canara (Cannanore, on the Malabar Coast, Kerala, India), coll. F. Day (only photograph examined); Day's material (syntype?), 1 ex., BMNH 1889.2.1.755, Wayanad, Kerala, India, coll. F. Day (only photograph examined); 3 exs., CRGSAC-2010.05.01-03, Cochin, Kerala, collected on 18.v.2010 by F. Baby; 6 exs. BNHS FWF 86-90, 92, Bandiwade, Gad River, Sindhudurg District, Maharashtra, collected on 15.ix.2013 by $U$. Katwate and S. Rane; 1 ex. BNHS FWF 91, collected from Terekhol River at Madkhol, Maharashtra, by U. Katwate, M. Paingankar and N. Dahanukar on 9.viii.2013.

Pethia setnai ( $\mathrm{n}=35)$ : Holotype, ZSI Kolkata FF2766, collected from Sanguem, Goa, by S. R. Sane on 1.iii.1985; Paratypes, 6 exs., ZSI Kolkata FF2767, collected from Sanguem, Goa, by S. R. Sane on 1.iii.1985; 9 exs. BNHS FWF 53, 63 to 70, collected from Sanguem, Goa, by $U$. Katwate, M. Paingankar and N. Dahanukar on 10.viii.2013; 3 exs.; WILD-13-PIS-043 to 045, collected from Sanguem, Goa, by U. Katwate, M. Paingankar and N. Dahanukar on 10.viii.2013; 2 exs., ZSI-WRC-P/3567, collected from Sanguem, Goa, by U. Katwate, M. Paingankar and N. Dahanukar on 10.viii.2013; 9 exs., BNHS FWF 54-62, collected from Terekhol River at Madkhol, Maharashtra, by U. Katwate and N. Dahanukar on 12.vi.2013; 3 exs., WILD-13-PIS-046 to 48, collected from Terekhol River at Madkhol, Maharashtra, by U. Katwate and N. Dahanukar on 12.vi.2013; 2 exs., ZSIWRC-P/3568, collected from Terekhol River at Madkhol, Maharashtra, by U. Katwate and N. Dahanukar on 12.vi.2013. Osteological details were obtained from Katwate et al. (2013).

Pethia narayani $(\mathrm{n}=2)$ : Syntypes, 2 exs., ZSI Kolkata F12180/1, collected from Cauvery River, Coorg, by C.R.N. Rao (only photographs examined).

Pethia pookodensis $(n=2): 2$ exs., specimens not collected, from Pookode lake, Kerala, by R. Raghavan and A. Ali, on 14.04.2004. Photographs are provided in Appendix C.

Puntius fraseri $(n=3)$ : Holotype (based on the note by R. Pethiyagoda in the specimen bottle), ZSI-K F12497/1, collected from Dharna River, Deolali, Bombay Presidency by A.G.L. Fraser; 2 exs., Paratypes, ZSI-K F12497/1, collected from Dharna River, Deolali, Bombay Presidency by A.G.L. Fraser.

Puntius deccanensis $(n=4)$ : Holotype, ZSI-K FF1925, collected from nalla near Katraj tank, Poona, by C. B. Prasad on 20.vii.1974; 1 ex., paratype FF1927, collected from nalla near Katraj tank, Poona, by B.K. Tikader on 13.ii.1976; 2 exs., paratypes, collected from nalla near Katraj tank, Poona, by C. B. Prasad on 20.vii.1974.

Pethia phutunio $(n=3)$ : 1 ex., BNHS-FWF-95, collected from Sambalpur, Odisha, by S. Jadhav, on 7 July 2012; 2 exs., BNHS FWF 93 and 94, collected from Hooghly, West Bengal, by R. Pandit on 12 May 2010.

Pethia muvattupuzhaensis: Data from Beevi \& Ramachandran (2005).

Pethia nigripinna: Data from Knight et al. (2012). Pethia macrogramma: Data from Kullander (2008). Pethia stoliczkana: Data from Linthoingambi \& Vishwanath (2007)

Pethia tiantian: Data from Kullander \& Fang (2005)

Pethia expletiforis: Data from Dishma \& Vishwanath (2013)

Pethia guganio: Data from Knight (2013).

Pethia ticto: Data from Linthoingambi \& Vishwanath (2007), Hora et al. (1939), Hamilton (1822).

Pethia nigrofasciata: Data from Jayaram (1991) and Pethiyagoda et al. (2012). 


\section{REFERENCES}

Ali, A., S. Philip, N. Dahanukar, C.R. Renjithkumar, A. Bijukumar \& R. Raghavan (2013). Distribution, threats and conservation status of Hypselobarbus thomassi (Day, 1874), a poorly known cyprinid fish of the Western Ghats freshwater ecoregion. Journal of Threatened Taxa 5(17): 5202-5213; http://dx.doi.org/10.11609/ JoTT.03838.5202-13

Altschul, S.F., W. Gish, W. Miller, E.W. Myers \& D.J. Lipman (1990). Basic local alignment search tool. Journal of Molecular Biology 215(3): 403-410; http://dx.doi.org/10.1016/S0022-2836(05)803602

Beevi, K.S.J. \& A. Ramachandran (2009). Checklist of freshwater fishes collected from Ernakulam District, Kerala, India. Journal of Threatened Taxa 1(9): 493-494; http://dx.doi.org/10.11609/JoTT. o1559.493-4

Beevi, K.S.J. \& A. Ramachandran (2005). A new species of Puntius (Cyprinidae, Cyprininae) from Kerala, India. Journal of the Bombay Natural History Society 102(1): 83-85.

Bini, L.M., J.A.F. Diniz-Filho, T.F. Rangel, R.P. Bastos \& M.P. Pinto (2006). Challenging Wallacean and Linnean shortfalls: knowledge gradients and conservation planning in a biodiversity hotspot. Diversity and Distributions 12(5): 475-482; http://dx.doi. org/10.1111/j.1366-9516.2006.00286.x

Chhapgar, B.F. \& S.R. Sane (1992). A new fish of the genus Puntius Hamilton (Ostariophysi: Cyprinidae) from Goa. Journal of the Bombay Natural History Society 89: 357-359.

Conway, K.W. (2011). Osteology of the South Asian genus Psilorhynchus McClelland, 1839 Teleostei: Ostariophysi: Psilorhynchidae), with investigation of its phylogenetic relationships within the order Cypriniformes. Zoological Journal of the Linnean Society 163: 150154; http://dx.doi.org/10.1111/j.1096-3642.2011.00698.x

Dahanukar, N. (2011). Puntius punctatus. In: IUCN 2013. IUCN Red List of Threatened Species. Version 2013.2. <www.iucnredlist.org>. Downloaded on 26 January 2014.

Dahanukar, N., R. Raghavan, A. Ali, R. Abraham \& C.P. Shaji (2011). The status and distribution of freshwater fishes of the Western Ghats, pp. 21-48. In: Molur, S., K.G. Smith, B.A. Daniel \& W.R.T. Darwall (compilers). The Status of Freshwater Biodiversity in The Western Ghats, India. International Union for Conservation of Nature (IUCN) Gland, Switzerland \& Zoo Outreach Organization (ZOO) Coimbatore, India, 116pp.

Day, F. (1865). On the fishes of Cochin, on the Malabar coast of India. Proceedings of the Zoological Society of London 33(1): 286-318. http://dx.doi.org/10.1111/j.1469-7998.1865.tb02337.x

Day, F. (1871). Monograph of Indian Cyprinidae. Parts 1-3. Journal and Proceedings of the Asiatic Society of Bengal 40: 95-142, 277367, 337-367.

Day, F. (1889). The fauna of British India, including Ceylon and Burma. Fishes - Vol. I. Taylor and Francis, London.

Deraniyagala, P.E.P. (1956). Two new subspecies and one new species of cyprinoid fishes from Ceylon. Proceedings of the 12th Annual Sessions of the Ceylon Association for the Advancement of Science, 1: 34-35.

Devi, K.R., T.J. Indra \& M.B. Raghunathan (2007). Ichthyofauna of Indira Gandhi Wildlife Sanctuary. Zoological Survey of India, Occasional Paper No. 277, Kolkata.

Devi, K.R., T.J. Indra, M.B. Raghunathan \& M.S. Ravichandran (2005). Fish fauna of the Anamalai Hill Ranges, Western Ghats, India. Zoos' Print Journal 20(3): 1809-1811; http://dx.doi.org/10.11609/JoTT. ZPJ.1164a.1809-11

Dishma, M. \& W. Vishwanath (2013). A new species of the genus Pethia from Mizoram, northeastern India (Teleostei: Cyprinidae). Zootaxa 3736(1): 082-088; http://dx.doi.org/10.11646/zootaxa.3736.1.4

Edgar, R.C. (2004). MUSCLE: multiple sequence alignment with high accuracy and high throughput. Nucleic Acids Research 32(5): 17921797; http://dx.doi.org/10.1093/nar/gkh340

Fraser, A.G.L. (1942). Fishes of Poona, Part - I \& II. Journal of the Bombay Natural History Society. 43: 79-91.
Günther, A. (1868). Catalogue of the fishes in the British Museum, vol. 7. British Museum, London, $\mathrm{i}-\mathrm{xx}+1-512 \mathrm{pp}$.

Gurung, D.B., Dorji, S., U. Tshering \& J.T. Wangyal (2013). An annotated checklist of fishes from Bhutan. Journal of Threatened Taxa 5(14): 4880-4886; http://dx.doi.org/10.11609/JoTT.03160.4880-6

Hamilton, F. (1822). An Account of the Fishes of River Ganges and its Branches. George Ramsay and Co., London, vii+405pp, 39pls.

Hora, S.L. (1937). Notes on fishes in the Indian Museum - XXVIII. On three collections of fish from Mysore and Coorg, south India. Records of the Indian Museum 39(1): 5-28.

Hora, S.L. \& K.S. Misra (1938). Fish of Deolali, Part III. Journal of the Bombay Natural History Society, 40: 20-38, pls. 1-3.

Hora, S.L., K.S. Misra \& G.M. Malik (1939). A study of variations in Barbus (Puntius) ticto (Hamilton). Records of Indian Museum 41: 263-279.

Jayaram, K.C. (2010). The Freshwater Fishes of the Indian Region. Second Edition. Narendra Publishing House, Delhi, 616pp.

Jayaram, K.C. (1991). Revision of the genus Puntius (Hamilton) from the Indian Region (Pisces: Cypriniformes, Cyprinidae, Cyprininae). Records of the Zoological Survey of India, Occasional Paper 135: 1-178.

Johnson, J.A. \& M. Arunachalam (2009). Diversity, distribution and assemblage structure of fishes in streams of southern Western Ghats, India. Journal of Threatened Taxa 1(10): 507-513; http:// dx.doi.org/10.11609/JoTT.02146.507-13

Katwate, C., R. Pawar, V. Shinde, D. Apte \& U. Katwate (2014). How long will social beliefs protect the pride of river Savitri. Min Newsletter of FFSG 2: 21-24.

Katwate, U., M.S. Paingankar, S. Jadhav \& N. Dahanukar (2013). Phylogenetic position and osteology of Pethia setnai (Chhapgar \& Sane, 1992), an endemic barb (Teleostei: Cyprinidae) of the Western Ghats, India, with notes on its distribution and threats. Journal of Threatened Taxa 5(17): 5214-5227; http://dx.doi.org/10.11609/ JoTT.03857.5214-27

Katwate, U., R. Raut \& S. Advani (2012). An overview of fish fauna of Raigad District, northern Western Ghats, India. Journal of Threatened Taxa 4(5): 2569-2577; http://dx.doi.org/10.11609/ JoTT.02760.2569-77

Kharat, S.S., N. Dahanukar \& R. Raut (2001). Decline of fresh-water fish of Pune urban area. Journal of Ecological Society 13/14: 46-51.

Knight, J.D.M. (2013). Pethia aurea (Teleostei: Cyprinidae), a new species of barb from West Bengal, India, with redescription of $P$. gelius and $P$. canius. Zootaxa 3700(1): 173-184; http://dx.doi. org/10.11646/zootaxa.3700.1.7

Knight, J.D.M., K.R. Devi, T.J. Indra \& M. Arunachalam (2012). A new species of barb Puntius nigripinnis (Teleostei: Cyprinidae) from southern Western Ghats, India. Journal of Threatened Taxa 4(3): 2409-2416; http://dx.doi.org/10.11609/JoTT.03014.2409-16

Kottelat, M. (2013). The fishes of the inland waters of Southeast Asia: a catalogue and core bibliography of the fishes known to occur in freshwaters, mangroves and estuaries. The Raffles Bulletin of Zoology 27: 1-663.

Kullander, S.O. (2008). Five new species of Puntius from Myanmar (Teleostei: Cyprinidae). Ichthyological Exploration of Freshwaters 19(1): 59-84.

Kullander, S.O. \& F. Fang (2005). Two new species of Puntius from northern Myanmar (Teleostei: Cyprinidae). Copeia(2): 290-302; http://dx.doi.org/10.1643/Cl-04-138R1

Linthoingambi, I. \& W. Vishwanath (2007). Two new fish species of the genus Puntius Hamilton (Cyprinidae) from Manipur, India, with notes on $P$. ticto (Hamilton) and $P$. stoliczkanus (Day). Zootaxa 1450: 45-56.

Menon, A.G.K. (1999). Check list - fresh water fishes of India. Records of the Zoological Survey of India, Miscellaneous Publication, Occasional Paper No. 175, 366pp.

Menon, A.G.K. \& K.R. Devi (1993). Puntius sharmai, a new cyprinid fish from Madras. Journal of the Bombay Natural History Society 89 : 353-354.

Mercy, T.V.A. \& E. Jacob (2007). A new species of Teleostei: Puntius 
Appendix A. Raw morphometric data for Pethia lutea sp. nov. All measurements are in mm.

\begin{tabular}{|c|c|c|c|c|c|c|c|c|c|c|c|c|c|}
\hline & $\begin{array}{c}\text { BNHS } \\
\text { FWF 71* }\end{array}$ & $\begin{array}{l}\text { BNHS } \\
\text { FWF } 72\end{array}$ & $\begin{array}{l}\text { WILD-14- } \\
\text { PIS-061 }\end{array}$ & $\begin{array}{l}\text { BNHS } \\
\text { FWF } 73\end{array}$ & $\begin{array}{l}\text { BNHS } \\
\text { FWF } 74\end{array}$ & $\begin{array}{l}\text { BNHS } \\
\text { FWF } 75\end{array}$ & $\begin{array}{l}\text { BNHS } \\
\text { FWF } 76\end{array}$ & $\begin{array}{l}\text { BNHS } \\
\text { FWF } 77\end{array}$ & $\begin{array}{l}\text { BNHS } \\
\text { FWF } 78\end{array}$ & $\begin{array}{l}\text { BNHS } \\
\text { FWF } 79\end{array}$ & $\begin{array}{c}\text { ZSI- } \\
\text { WRC-P } \\
\text { /3686 }\end{array}$ & $\begin{array}{l}\text { BNHS } \\
\text { FWF } 80\end{array}$ & $\begin{array}{l}\text { BNHS } \\
\text { FWF } 81\end{array}$ \\
\hline Total length & 40.2 & 40.5 & 44.1 & 49.4 & 39.8 & 34.2 & 33.5 & 34.9 & 38.8 & 44.5 & 38.1 & 49.2 & 40.8 \\
\hline $\begin{array}{l}\text { Standard } \\
\text { length }\end{array}$ & 30.8 & 30.9 & 35.0 & 38.9 & 30.9 & 26.2 & 25.3 & 26.7 & 29.3 & 34.6 & 30.5 & 39.0 & 33.2 \\
\hline Head length & 8.4 & 8.4 & 8.6 & 9.5 & 8.3 & 7.3 & 7.2 & 7.2 & 7.6 & 9.6 & 8.2 & 9.6 & 8.5 \\
\hline Head depth & 7.3 & 7.4 & 7.8 & 8.7 & 6.9 & 6.3 & 6.1 & 6.3 & 6.7 & 8.2 & 7.1 & 9.0 & 7.5 \\
\hline Head width & 5.0 & 5.0 & 5.4 & 5.5 & 5.0 & 4.1 & 4.0 & 4.1 & 4.4 & 5.6 & 5.0 & 5.7 & 4.7 \\
\hline Body depth & 11.2 & 10.4 & 11.9 & 12.2 & 11.0 & 9.8 & 8.6 & 8.9 & 10.3 & 12.5 & 10.7 & 13.2 & 11.1 \\
\hline $\begin{array}{l}\text { Body width } \\
\text { at Dorsal fin } \\
\text { origin }\end{array}$ & 5.3 & 4.5 & 5.5 & 5.8 & 5.1 & 4.1 & 4.1 & 4.1 & 3.4 & 5.6 & 5.1 & 4.9 & 4.3 \\
\hline $\begin{array}{l}\text { Body width at } \\
\text { anal fin origin }\end{array}$ & 4.0 & 3.2 & 4.3 & 4.1 & 3.5 & 2.9 & 3.0 & 3.2 & 2.1 & 4.6 & 3.6 & 3.1 & 3.0 \\
\hline Snout length & 2.2 & 2.2 & 2.3 & 2.6 & 2.3 & 1.9 & 2.0 & 2.0 & 1.9 & 2.5 & 2.2 & 2.5 & 1.9 \\
\hline Eye diameter & 2.6 & 2.8 & 2.8 & 3.0 & 2.7 & 2.2 & 2.3 & 2.4 & 2.7 & 2.9 & 2.9 & 3.1 & 2.5 \\
\hline $\begin{array}{l}\text { Inter orbital } \\
\text { width }\end{array}$ & 3.1 & 3.4 & 3.5 & 3.7 & 3.3 & 2.6 & 2.6 & 2.7 & 2.7 & 3.7 & 3.3 & 3.4 & 2.7 \\
\hline $\begin{array}{l}\text { Pre dorsal } \\
\text { distance }\end{array}$ & 16.0 & 15.7 & 17.7 & 20.5 & 15.8 & 13.8 & 13.4 & 13.5 & 15.5 & 18.1 & 15.6 & 20.1 & 17.5 \\
\hline $\begin{array}{l}\text { Dorsal to } \\
\text { hypural } \\
\text { distance }\end{array}$ & 15.3 & 15.3 & 17.2 & 18.6 & 15.0 & 12.2 & 12.7 & 12.8 & 14.1 & 16.1 & 15.2 & 18.6 & 16.2 \\
\hline $\begin{array}{l}\text { Prepelvic } \\
\text { distance }\end{array}$ & 15.6 & 15.4 & 17.3 & 19.1 & 15.5 & 13.1 & 12.8 & 13.0 & 14.3 & 17.6 & 15.1 & 19.8 & 17.1 \\
\hline $\begin{array}{l}\text { Preanal } \\
\text { distance }\end{array}$ & 22.1 & 21.9 & 24.7 & 28.8 & 22.1 & 18.4 & 18.5 & 18.9 & 20.6 & 24.8 & 22.2 & 29.4 & 24.4 \\
\hline $\begin{array}{l}\text { Prepectoral } \\
\text { distance }\end{array}$ & 8.6 & 8.9 & 9.3 & 10.2 & 8.6 & 7.4 & 7.4 & 7.4 & 8.3 & 10.0 & 8.6 & 10.1 & 8.8 \\
\hline $\begin{array}{l}\text { Dorsal fin } \\
\text { length }\end{array}$ & 6.9 & 8.3 & 8.8 & 9.6 & 8.0 & 6.9 & 6.4 & 7.6 & 7.9 & 9.7 & 7.8 & 9.3 & 8.7 \\
\hline $\begin{array}{l}\text { Dorsal fin } \\
\text { spine length }\end{array}$ & 5.6 & 5.3 & 5.8 & 5.7 & 5.6 & 4.8 & 4.6 & 5.2 & 4.8 & 5.8 & 4.9 & 5.4 & 5.5 \\
\hline $\begin{array}{l}\text { Length of } \\
\text { Dorsal fin base }\end{array}$ & 4.9 & 5.1 & 5.7 & 5.8 & 5.2 & 4.3 & 3.9 & 4.3 & 4.1 & 5.8 & 5.0 & 5.0 & 4.9 \\
\hline $\begin{array}{l}\text { Pectoral fin } \\
\text { length }\end{array}$ & 5.9 & 6.8 & 7.0 & 7.9 & 6.6 & 4.8 & 5.5 & 5.7 & 5.5 & 7.8 & 6.7 & 7.9 & 6.7 \\
\hline Anal fin depth & 5.6 & 6.2 & 6.7 & 7.4 & 6.0 & 4.7 & 4.9 & 5.2 & 5.4 & 7.0 & 6.0 & 5.8 & 6.8 \\
\hline $\begin{array}{l}\text { Caudal } \\
\text { peduncle } \\
\text { length }\end{array}$ & 6.2 & 5.8 & 6.5 & 8.3 & 6.1 & 5.4 & 5.2 & 5.4 & 6.4 & 6.8 & 5.4 & 8.6 & 6.6 \\
\hline $\begin{array}{l}\text { Caudal } \\
\text { peduncle } \\
\text { depth }\end{array}$ & 4.8 & 4.5 & 5.1 & 5.9 & 4.8 & 4.1 & 3.6 & 3.7 & 4.2 & 5.4 & 4.5 & 5.7 & 4.6 \\
\hline
\end{tabular}

pookodensis (Cyprinidae) from Wayanad, Kerala, India. Journal of the Bombay Natural History Society 104(1):76-78.

Nei, M. \& S. Kumar (2000). Molecular Evolution and Phylogenetics. Oxford University Press, New York, 333pp.

Pethiyagoda, R., M. Meegaskumbura \& K. Maduwage (2012). A synopsis of the South Asian fishes referred to Puntius (Pisces: Cyprinidae). Ichthyological Exploration of Freshwaters 23(1): 69-95.

Potthoff, T. (1984). Clearing and staining techniques, pp. 35-37. In: Moser, H.G., W.J. Richards, D.M. Cohen, M.P. Fahay, A.W. Kendall, Jr. \& S.L. Richardson (eds.). Ontogeny and Systematics of Fishes. American Society for Ichthyology and Herpetology, Special Publication No. 1., 760pp.

Schwarz, G. (1978). Estimating the dimension of a model. Annals of Statistics 6: 461-464.

Shaji, C.P. \& P.S. Easa (1995). Freshwater fish diversity in Wayanad, Kerala, South India. Journal of Zoological Society of Kerala 5(1\&2): 30-36.
Silas, E.G. (1952). Further studies regarding Hora's Satpura hypothesis 2. Taxonomic assessment and levels of evolutionary divergences of fishes with the so-called Malayan affinities in peninsular India. Proceedings of the National Institute of Sciences of India 18(5): 423-448.

Suter, M.J. (1944). New records of fish from Poona. Journal of the Bombay Natural History Society 44: 408-414.

Talwar, P.K. \& A.G. Jhingran (1991). Inland Fishes of India and Adjacent Countries - Volume 1. Oxford \& IBH Publishing Co. Pvt. Ltd., New Delhi, 541pp.

Tamura, K. \& M. Nei (1993). Estimation of the number of nucleotide substitutions in the control region of mitochondrial DNA in humans and chimpanzees. Molecular Biology and Evolution 10(3): 512-526.

Tamura, K., G. Stecher, D. Peterson, A. Filipski \& S. Kumar (2013). MEGA6: Molecular Evolutionary Genetics Analysis version 6.0. Molecular Biology and Evolution 30: 2725-2729; http://dx.doi. org/10.1093/molbev/mst197 
Appendix A: contd.

\begin{tabular}{|c|c|c|c|c|c|c|c|c|c|}
\hline & $\begin{array}{c}\text { BNHS } \\
\text { FWF } 82\end{array}$ & $\begin{array}{l}\text { WILD-14- } \\
\text { PIS-062 }\end{array}$ & $\begin{array}{c}\text { ZSI- } \\
\text { WRC-P/3687 }\end{array}$ & $\begin{array}{l}\text { WILD-14- } \\
\text { PIS-063 }\end{array}$ & $\begin{array}{c}\text { ZSI- } \\
\text { WRC-P/3688 }\end{array}$ & $\begin{array}{c}\text { BNHS } \\
\text { FWF } 83\end{array}$ & $\begin{array}{c}\text { BNHS } \\
\text { FWF } 84\end{array}$ & $\begin{array}{l}\text { BNHS } \\
\text { FWF } 85 \\
\end{array}$ & $\begin{array}{l}\text { WILD-14- } \\
\text { PIS-064 }\end{array}$ \\
\hline Total length & 40.6 & 29.9 & 31.4 & 38.3 & 30.8 & 30.8 & 28.8 & 28.9 & 28.2 \\
\hline \begin{tabular}{|l} 
Standard \\
length
\end{tabular} & 31.7 & 22.5 & 23.4 & 30.7 & 23.4 & 23.4 & 21.5 & 21.9 & 20.9 \\
\hline Head length & 8.4 & 6.4 & 6.7 & 8.6 & 6.4 & 6.4 & 6.1 & 6.6 & 6.0 \\
\hline Head depth & 7.4 & 5.0 & 5.4 & 6.6 & 5.6 & 5.6 & 5.4 & 5.2 & 4.8 \\
\hline Head width & 5.1 & 3.6 & 3.7 & 5.0 & 3.9 & 3.8 & 3.5 & 3.6 & 3.3 \\
\hline Body depth & 10.7 & 7.7 & 8.3 & 10.6 & 7.9 & 8.1 & 7.3 & 7.2 & 6.5 \\
\hline $\begin{array}{l}\text { Body width } \\
\text { at Dorsal fin } \\
\text { origin } \\
\end{array}$ & 4.9 & 3.5 & 3.7 & 4.8 & 3.5 & 3.6 & 3.2 & 3.3 & 2.2 \\
\hline $\begin{array}{l}\text { Body width at } \\
\text { anal fin origin }\end{array}$ & 4.0 & 2.5 & 2.6 & 4.0 & 2.8 & 2.6 & 2.5 & 2.8 & 1.2 \\
\hline Snout length & 2.2 & 1.7 & 1.7 & 2.3 & 1.6 & 1.7 & 1.4 & 1.7 & 1.5 \\
\hline Eye diameter & 2.9 & 2.0 & 2.2 & 2.5 & 2.1 & 2.2 & 2.1 & 2.1 & 2.1 \\
\hline $\begin{array}{l}\text { Inter orbital } \\
\text { width }\end{array}$ & 3.4 & 2.0 & 2.3 & 3.4 & 2.5 & 2.5 & 2.4 & 2.1 & 2.3 \\
\hline \begin{tabular}{|l} 
Pre dorsal \\
distance
\end{tabular} & 16.3 & 11.8 & 12.1 & 16.0 & 12.0 & 12.3 & 11.1 & 11.2 & 10.9 \\
\hline \begin{tabular}{|l} 
Dorsal to \\
hypural \\
distance
\end{tabular} & 16.0 & 10.3 & 11.4 & 15.0 & 11.1 & 11.2 & 10.2 & 10.7 & 10.0 \\
\hline \begin{tabular}{|l} 
Prepelvic \\
distance
\end{tabular} & 15.5 & 11.5 & 11.6 & 14.5 & 11.8 & 11.9 & 10.9 & 11.6 & 10.7 \\
\hline \begin{tabular}{|l|} 
Preanal \\
distance
\end{tabular} & 22.2 & 16.3 & 16.6 & 21.2 & 16.5 & 16.7 & 15.3 & 15.6 & 16.1 \\
\hline \begin{tabular}{|l} 
Prepectoral \\
distance
\end{tabular} & 8.8 & 7.0 & 6.9 & 8.1 & 7.0 & 7.1 & 6.4 & 6.9 & 6.1 \\
\hline \begin{tabular}{|l} 
Dorsal fin \\
length
\end{tabular} & 8.1 & 6.3 & 6.7 & 8.1 & 6.7 & 6.8 & 6.7 & 6.6 & 6.4 \\
\hline \begin{tabular}{|l}
$\begin{array}{l}\text { Dorsal fin } \\
\text { spine length }\end{array}$ \\
\end{tabular} & 5.5 & 5.0 & 4.3 & 4.9 & 5.0 & 4.8 & 4.3 & 5.3 & 4.3 \\
\hline $\begin{array}{l}\text { Length of } \\
\text { Dorsal fin base }\end{array}$ & 5.2 & 3.5 & 3.5 & 5.2 & 3.9 & 4.0 & 3.8 & 3.7 & 3.3 \\
\hline \begin{tabular}{|l} 
Pectoral fin \\
length
\end{tabular} & 6.9 & 5.5 & 4.9 & 6.7 & 4.8 & 5.0 & 4.6 & 4.6 & 4.5 \\
\hline Anal fin depth & 6.3 & 4.8 & 4.8 & 6.2 & 5.0 & 5.0 & 4.2 & 4.7 & 4.2 \\
\hline \begin{tabular}{|l} 
Caudal \\
peduncle \\
length \\
\end{tabular} & 6.1 & 4.3 & 4.6 & 5.7 & 4.8 & 5.0 & 4.4 & 4.6 & 4.5 \\
\hline \begin{tabular}{|l|} 
Caudal \\
peduncle \\
depth \\
\end{tabular} & 5.0 & 3.0 & 3.5 & 4.5 & 3.5 & 3.6 & 2.9 & 3.2 & 3.3 \\
\hline
\end{tabular}

Tonapi, G.T. \& L. Mulherkar (1963). Notes on the freshwater fauna of Poona, Part:1, Fishes. Proceedings of the Indian Academy of Sciences 58: 187-197; http://dx.doi.org/10.1007/BF03051937

Wagh, G.K. \& H.V. Ghate (2003). Freshwater fish fauna of the rivers Mula and Mutha, Pune, Maharashtra. Zoos' Print Journal 18(1): 977-981; http://dx.doi.org/10.11609/JoTT.ZPJ.18.1.977-89

Yazdani, G.M. \& M.B. Rao (1976). A new species of the genus Puntius (Hamilton) (Pisces: Cypriniformes: Cyprinidae) from western India. Journal of the Bombay Natural History Society 73: 171-175.
Author Details: UNMESH KATWATE is a Zoology (Oceanography) postgraduate currently working as Scientist-A in Bombay Natural History Society (BNHS). He works on conservation, taxonomy and ecological aspects of freshwater fishes and amphibians of the Western Ghats. CHETANA KatWATE is a Research Associate in BNHS. She works on freshwater fish osteology and is interested in understanding its evolutionary significance. She is also interested in ecology and conservation. RAIEEV RAGHAVAN is interested in interdisciplinary research focused on generating information and developing methods to support conservation decision-making in freshwater ecosystems. MANDAR S. PAINGANKAR is a molecular biologist and works on vector biology with an emphasis on host parasite interactions. He works on molecular phylogeny and systematics of freshwater fishes as a hobby. NEELESH DAHANUKAR works in ecology and evolution with an emphasis on mathematical and statistical analysis. He is also interested in taxonomy, distribution patterns and molecular phylogeny of freshwater fish and amphibians. 
Appendix B. Raw morphometric data for Pethia punctata. All measurements are in $\mathrm{mm}$

\begin{tabular}{|c|c|c|c|c|c|c|c|c|c|c|}
\hline & $\begin{array}{c}\text { BNHS } \\
\text { FWF } 86 \\
\end{array}$ & $\begin{array}{l}\text { BNHS } \\
\text { FWF } 87 \\
\end{array}$ & $\begin{array}{l}\text { BNHS } \\
\text { FWF } 88\end{array}$ & $\begin{array}{l}\text { BNHS } \\
\text { FWF } 89\end{array}$ & $\begin{array}{l}\text { BNHS } \\
\text { FWF } 90 \\
\end{array}$ & $\begin{array}{l}\text { BNHS } \\
\text { FWF } 91 \\
\end{array}$ & $\begin{array}{l}\text { BNHS } \\
\text { FWF } 92\end{array}$ & $\begin{array}{l}\text { CRGSAC- } \\
2010.05 .01 \\
\end{array}$ & $\begin{array}{c}\text { CRGSAC- } \\
2010.05 .02 \\
\end{array}$ & $\begin{array}{c}\text { CRGSAC- } \\
2010.05 .03 \\
\end{array}$ \\
\hline Total length & 53.7 & 42.0 & 38.3 & 40.6 & 34.8 & 34.2 & 46.2 & 62.7 & 59.3 & 53.1 \\
\hline Standard length & 41.2 & 32.9 & 29.1 & 30.9 & 28.1 & 26.3 & 36.5 & 50.2 & 46.9 & 40.7 \\
\hline Head length & 12.1 & 9.4 & 8.5 & 9.7 & 8.6 & 7.6 & 11.2 & 12.0 & 12.3 & 10.8 \\
\hline Head depth & 9.7 & 7.0 & 7.5 & 6.8 & 6.2 & 4.9 & 8.0 & 9.7 & 9.5 & 8.3 \\
\hline Head width & 5.9 & 4.7 & 5.1 & 4.3 & 4.1 & 3.7 & 5.3 & 7.0 & 6.9 & 5.5 \\
\hline Body depth & 16.2 & 12.6 & 11.7 & 12.5 & 11.0 & 10.0 & 13.5 & 16.6 & 16.8 & 15.2 \\
\hline $\begin{array}{l}\text { Body width at } \\
\text { Dorsal fin origin }\end{array}$ & 6.1 & 4.7 & 4.8 & 3.7 & 3.2 & 3.3 & 5.4 & 7.4 & 7.1 & 5.7 \\
\hline $\begin{array}{l}\text { Body width at anal } \\
\text { fin origin }\end{array}$ & 4.9 & 3.6 & 4.1 & 2.8 & 2.6 & 2.3 & 4.5 & 6.0 & 5.4 & 5.2 \\
\hline Snout length & 2.9 & 2.4 & 2.6 & 2.6 & 2.3 & 2.3 & 3.1 & 3.4 & 4.5 & 3.3 \\
\hline Eye diameter & 3.4 & 2.9 & 3.0 & 2.9 & 2.9 & 2.7 & 3.3 & 3.6 & 4.0 & 3.3 \\
\hline Inter orbital width & 4.1 & 3.2 & 3.6 & 3.3 & 2.9 & 2.6 & 3.8 & 3.9 & 4.1 & 3.7 \\
\hline Pre dorsal distance & 22.1 & 16.8 & 14.9 & 16.7 & 15.4 & 13.6 & 18.6 & 23.4 & 22.6 & 20.7 \\
\hline $\begin{array}{l}\text { Dorsal to hypural } \\
\text { distance }\end{array}$ & 19.2 & 16.0 & 14.2 & 15.0 & 12.5 & 13.0 & 18.3 & 28.3 & 25.9 & 21.9 \\
\hline Prepelvic distance & 21.2 & 16.3 & 14.9 & 15.2 & 14.7 & 13.3 & 18.1 & 24.2 & 22.1 & 20.1 \\
\hline Preanal distance & 30.4 & 22.8 & 21.8 & 22.1 & 21.1 & 19.3 & 26.4 & 35.3 & 34.3 & 29.5 \\
\hline $\begin{array}{l}\text { Prepectoral } \\
\text { distance }\end{array}$ & 12.0 & 9.3 & 8.8 & 9.8 & 8.8 & 7.5 & 11.2 & 13.0 & 12.5 & 11.1 \\
\hline Dorsal fin length & 11.4 & 9.4 & 9.3 & 8.8 & 7.8 & 7.9 & 9.4 & 13.6 & 12.9 & 10.0 \\
\hline $\begin{array}{l}\text { Dorsal fin spine } \\
\text { length }\end{array}$ & 7.9 & 7.3 & 7.2 & 6.4 & 5.3 & 6.3 & 6.6 & - & - & - \\
\hline $\begin{array}{l}\text { Length of Dorsal } \\
\text { fin base }\end{array}$ & 5.7 & 5.4 & 4.9 & 4.9 & 4.5 & 4.2 & 5.4 & 9.4 & 8.5 & 7.5 \\
\hline Pectoral fin length & 8.0 & 7.0 & 6.0 & 5.8 & 5.4 & 4.6 & 7.9 & 10.0 & 9.2 & 8.3 \\
\hline Anal fin depth & 6.9 & 5.4 & 5.5 & 5.3 & 4.7 & 4.9 & 6.0 & 7.7 & 7.5 & 7.9 \\
\hline $\begin{array}{l}\text { Caudal peduncle } \\
\text { length }\end{array}$ & 7.5 & 5.6 & 4.9 & 5.9 & 4.9 & 5.3 & 6.4 & 9.8 & 8.5 & 8.7 \\
\hline $\begin{array}{l}\text { Caudal peduncle } \\
\text { depth }\end{array}$ & 6.2 & 4.7 & 4.7 & 4.6 & 4.2 & 3.9 & 5.4 & 6.9 & 6.6 & 6.1 \\
\hline
\end{tabular}

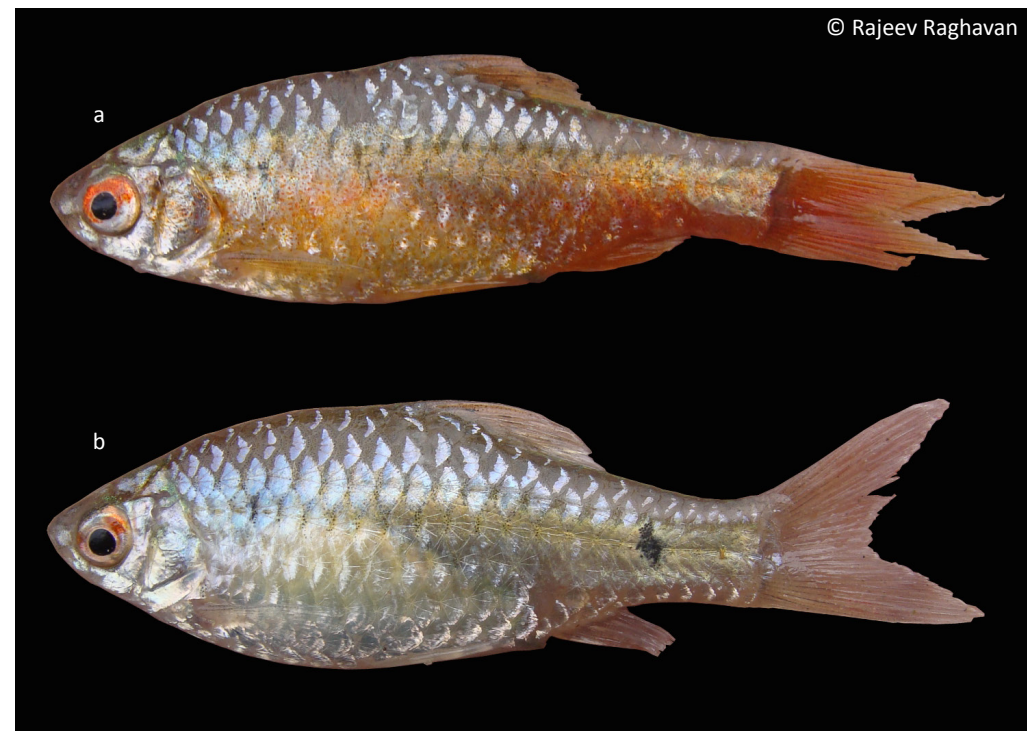

Appendix C. Pethia pookodensis male (a) and female (b) from Pookode Lake, Kerala. 